\title{
Experimental and Computational Studies of Ruthenium(II)-Catalyzed Addition of Arene C-H Bonds to Olefins
}

\author{
Marty Lail, ${ }^{\dagger}$ Christen M. Bell, ${ }^{\dagger}$ David Conner, ${ }^{\dagger}$ Thomas R. Cundari, ${ }^{\ddagger}$ \\ T. Brent Gunnoe, ${ }^{* \dagger}$ and J effrey L. Petersen ${ }^{\S}$ \\ Department of Chemistry, North Carolina State University, \\ Raleigh, North Carolina 27695-8204, Department of Chemistry, University of North Texas, \\ Box 305070, Denton, Texas 76203-5070, and C. Eugene Bennett Department of Chemistry, \\ West Virginia University, Morgantown, West Virginia 26506-6045
}

Received August 2, 2004

\begin{abstract}
Hydroarylation reactions of ol efins are catalyzed by the octahedral Ru(II) complex TpRu(CO)(NCMe)(Ph) (1) (Tp = hydridotris(pyrazolyl)borate). Experimental studies and density functional theory calculations support a reaction pathway that involves initial acetonitrile/ olefin ligand exchange and subsequent ol efin insertion into the ruthenium-phenyl bond. Metal-mediated $\mathrm{C}-\mathrm{H}$ activation of arene to form a Ru-aryl bond with rel ease of alkyl arene completes the proposed catalytic cycle. The cyclopentadienyl complex $\mathrm{CpRu}\left(\mathrm{PPh}_{3}\right)_{2}(\mathrm{Ph})$ produces ethyl benzene and styrene from a benzene/ethylene solution at $90^{\circ} \mathrm{C}$; however, the transformation is not catalytic. A benzene solution of $(\mathrm{PCP}) \mathrm{Ru}(\mathrm{CO})(\mathrm{Ph})\left(\mathrm{PCP}=2,6-\left(\mathrm{CH}_{2} \mathrm{Pt}_{-}\right.\right.$ $\left.\mathrm{Bu}_{2}\right)_{2} \mathrm{C}_{6} \mathrm{H}_{3}$ ) and ethylene at $90{ }^{\circ} \mathrm{C}$ produces styrene in $12 \%$ yield without observation of ethyl benzene. Computational studies (DFT) suggest that the $\mathrm{C}-\mathrm{H}$ activation step does not proceed through the formation of a Ru(IV) oxidative addition intermediate but rather occurs by a concerted pathway.
\end{abstract}

\section{Introduction}

The activation of $\mathrm{C}-\mathrm{H}$ bonds using transition metal complexes has received attention due to the chemically inert nature of the $\mathrm{C}-\mathrm{H}$ bond. ${ }^{1-4}$ The availability of aromatic compounds renders the development of methods for catalytic aromatic $\mathrm{C}-\mathrm{H}$ functionalization an area of significance. For example, the production of alkyl arenes is performed on a large scale. ${ }^{5}$ Simple $\sigma$-Lewis acid catalysts can be used for the synthesis of alkyl arenes by activating ol efins toward el ectrophilic addition to arenes; ${ }^{6,7}$ however, due to the formation of species with carbocationic character, products with linear alkyl chains cannot be accessed with these traditional catalytic methods. Linear alkyl arenes can be produced in low yields by Friedel-Crafts alkylation of arenes using 1-haloalkanes or by acylation of arenes followed by Clemmensen reduction of the carbonyl fragment. Other

* To whom correspondence should be addressed. E-mail: brent_gunnoe@ncsu.edu.

+ North Carolina State University.

₹ University of North Texas.

$\S$ West Virginia University.

(1) Davies, J . A.; Watson, P. L.; Liebman, J . F.; Greenberg, A. Selective Hydrocarbon Activation; VCH: New York, 1990.

(2) Ritleng, V.; Sirlin, C.; Pfeffer, M. Chem. Rev. 2002, 102, 17311769.

(3) Arndtsen, B. A.; Bergman, R. G.; Mobley, T. A.; Peterson, T. H. Acc. Chem. Res. 1995, 28, 154-162.

(4) Labinger, J . A.; Bercaw, J . E. Nature 2002, 417, 507-514.

(5) Chenier, P. J . Survey of I ndustrial Chemistry; Wiley-VCH: New York, 1992; Vol. 2.

(6) Roberts, R. M.; Khalaf, A. A. Friede-Crafts Alkylation Chemistry: A Century of Discovery; Marcel Dekker: New York, 1984.

(7) Patinkin, S. H.; Friedman, B. S. In Friede-Crafts and Related Reactions; Olah, G. A., Ed.; J ohn Wiley and Sons: New York, 1964; Vol. 2, pp 1-288. methods for $\mathrm{C}-\mathrm{C}$ bond-forming reactions involving aromatic molecules include transformations that typically incorporate aryl halides, and the preparation of aryl halides often requires multistep syntheses. ${ }^{8-14}$ Whereas these methodologies have been widely incorporated for the synthesis of small organic molecules, $\mathrm{C}-\mathrm{C}$ bond-forming reactions of aromatic molecules that proceed through metal-mediated $\mathrm{C}-\mathrm{H}$ rather than $\mathrm{C}-\mathrm{X}$ ( $\mathrm{X}=$ halide) bond activation would expand the scope of available transformations and reduce the need for aryl halide syntheses.

Significant advances in catalytic metal-mediated $\mathrm{C}-\mathrm{H}$ activation have been achieved for aromatic systems; ${ }^{2,15}$ however, such reactions are primarily limited to compounds that possess heteroatomic functionality tethered to the aromatic ring or carbonylation reactions of heteroaromatic substrates. ${ }^{16-24} \mathrm{M}$ etal-catalyzed conver-

(8) Heck, R. F. In Comprehensive Organic Synthesis; Trost, B. M., Fleming, I., Semmelhack, M. F., Eds.; Pergamon Press: Oxford, 1999; Vol. 4, pp 833-863.

(9) Beletskaya, I. P.; Cheprakov, A. V. Chem. Rev. 2000, 100, 30093066.

(10) Hassan, J.: Sévignon, M.; Gozzi, C.; Shulz, E.; Lemaire, M. Chem. Rev. 2002, 102, 1359-1469.

(11) Miyaura, N.; Suzuki, A. Chem. Rev. 1995, 95, 2457-2483.

(12) Fanta, P. E. Synthesis 1974, 9-21.

(13) Stille, J. K. Angew. Chem., Int. Ed. Engl. 1986, 25, 508-524.

(14) Bolm, C.; Hildebrand, J. P.; Muniz, K.; Hermanns, N. Angew. Chem. Int. Ed. 2001, 40, 3284-3308.

(15) Guari, Y.; Sbao-Etienne, S.; Chaudret, B. Eur. J . Inorg. Chem 1999, 1047-1055.

(16) Murai, S.; Kakiuchi, F.; Sekine, S.; Tanaka, Y.; Kamatani, A.; Sonoda, M.; Chatani, N. Nature 1993, 366, 529-531.

(17) Murai, S.; Kakiuchi, F.; Sekine, S.; Tanaka, Y.; Kamatani, A.; Sonoda, M.; Chatani, N. Pure Appl. Chem. 1994, 66, 1527-1534.

(18) Kakiuchi, F.; Yamamoto, Y.; Chatani, N.; Murai, S. Chem. Lett. 1995, 681-682. 
Table 1. Catalytic Addition of Arenes to Unsaturated Substrates (unless otherwise noted, reaction conditions are $90^{\circ} \mathrm{C}, 25 \mathrm{psi}$ of gas, $0.1 \mathrm{~mol} \%$ of 1, $4 \mathrm{~h}$ )

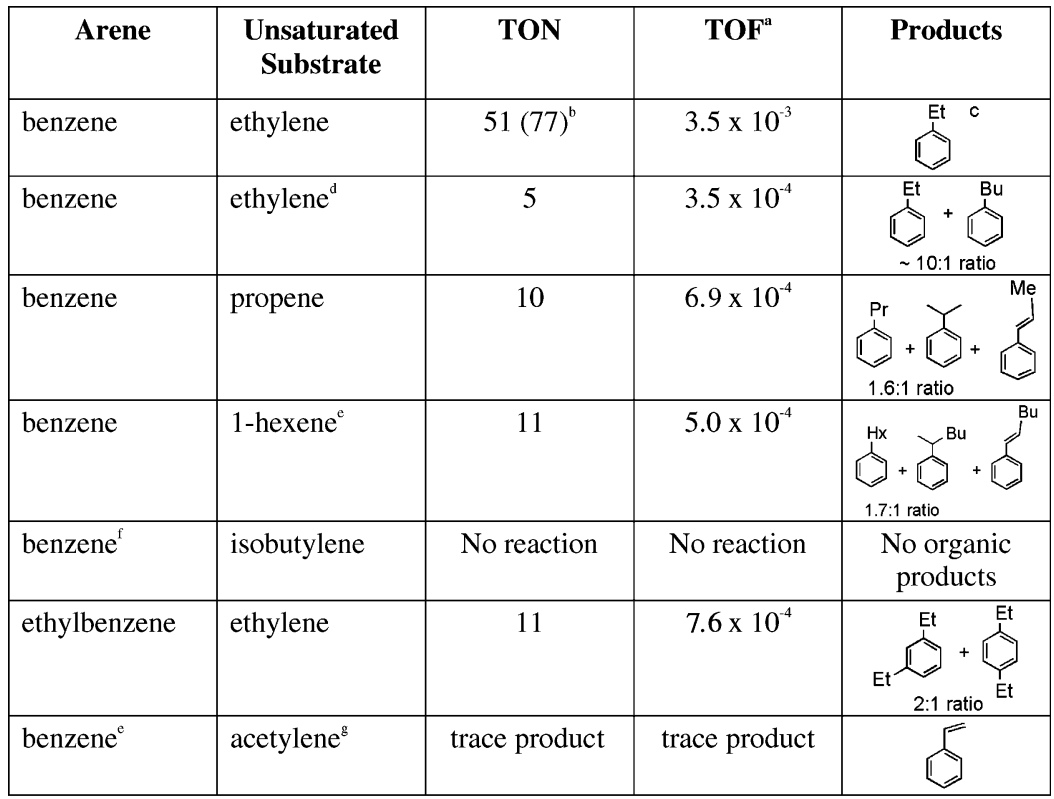

a mol $\mathbf{1}^{-1} \mathrm{~s}^{-1}$. b Turnovers observed after $24 \mathrm{~h}$ are given in parentheses. ${ }^{c}$ Trace quantities of 1,3- and 1,4-diethylbenzene are also produced. d At 250 psi of ethylene. e 50 equiv based on 1, after 6 h. ${ }^{\text { }} 24$ h. 910 psi.

sion of aromatic compounds and olefins to styrenes have been reported, ${ }^{25-29}$ and $\mathrm{Pd}$ or Pt systems can catalyze the addition of the $\mathrm{C}-\mathrm{H}$ bonds of nonfunctionalized aromatic compounds across unsaturated $\mathrm{C}-\mathrm{C}$ bonds. ${ }^{29-32}$ $\mathrm{Ru}(\mathrm{III})$ and $\mathrm{Au}(\mathrm{III})$ complexes catalyze intra- and intermolecular ol efin/alkyne hydroarylation. ${ }^{33,34}$ Catalytic borylation of aromaticsubstrateshasal sobeen reported. ${ }^{35-38}$ Most relevant to the present research are I r-catalyzed

(19) Thalji, R. K.; Ahrendt, K. A.; Bergman, R. G.; Ellman, J . A. J . Am. Chem. Soc. 2001, 123, 9692-9693.

(20) Tan, K. L.; Bergman, R. G.; Ellman, J . A. J . Am. Chem. Soc. 2001, 123, 2685-2686.

(21) Lenges, C. P.; Brookhart, M. J . Am. Chem. Soc. 1999, 121 $6616-6623$

(22) Chatani, N.; Ie, Y.; Kakiuchi, F.; Murai, S. J . Org. Chem. 1997, $62,2604-2610$.

(23) Fukuyama, T.; Chatani, N.: Tatsumi, J :; Kakiuchi, F.: Murai, S. J . Am. Chem. Soc. 1998, 120, 11522-11523.

(24) Chatani, N.; Fukuyama, T.; Kakiuchi, F.; Murai, S. J . Am. Chem. Soc. 1996, 118, 493-494.

(25) Sasaki, K.; Sakakura, T.; Tokunaga, Y.; Wada, K.; Tanaka, M. Chem. Lett. 1988, 685-688.

(26) Hong, P.; Yamazaki, H. J . Mol. Catal. 1984, 26, 297-311

(27) Weissman, H.; Song, X.; Milstein, D. J . Am. Chem. Soc. 2001 123, 337-338.

(28) Matsumoto, T.; Yoshida, H. Chem. Lett. 2000, 1064-1065.

(29) J ia, C.; Lu, W.; Kitamura, T.; Fujiwara, Y. Org. Lett. 1999, 1, 2097-2100

(30) J ia, C.; Piao, D.; Oyamada, J .; Lu, W.; Kitamura, T.; Fujiwara, Y. Science 2000, 287, 1992-1995.

(31) Boele, M. D. K.: van Strijdonck, G. P. F.; de Vries, A. H. M. Kamer, P. C. J .; de Vries, J. G.: van Leeuwen, P. W. N. M. J. Am. Chem. Soc. 2002, 124, 1586-1587.

(32) Pastine, S. J .; Youn, S. W.; Sames, D. Org. Lett. 2003, 5, 10551058.

(33) Youn, S. W.; Pastine, S. J .; Sames, D. Org. Lett. 2004, 6, 581584.

(34) Shi, Z.; He, C. J . Org. Chem. 2004, 69, 3669-3671.

(35) Cho, J.-Y.; Tse, M. K.; Holmes, D.; Maleczka, R. E.; Smith, M. R., III. Science 2002, 295, 305-308.

(36) I verson, C. N.; Smith, M. R., III. J . Am. Chem. Soc. 1999, 121, $7696-7697$.

(37) Cho, J .-Y.; I verson, C. N.; Smith, M. R., III . J . Am. Chem. Soc. 2000, 122, 12868-12869.

(38) Chen, H.; Schlecht, S.; Semple, T. C.; Hartwig, J . F. Science 2000, 287, 1995-1997. olefin hydroarylation reactions. ${ }^{39-42}$ We now disclose a combined experimental and computational study of a $\mathrm{Ru}(\mathrm{II})$ system that activates the $\mathrm{C}-\mathrm{H}$ bonds of arenes including the details of the catalytic addition of arenes to unsaturated $\mathrm{C}-\mathrm{C}$ bonds. ${ }^{43}$

\section{Results and Discussion}

Catalytic Hydroarylation of Olefins. At el evated temperatures, TpRu(CO)(NCMe)(Ph) (1) (Tp = hydridotris(pyrazolyl)borate) serves as a catalyst for the addition of arene $\mathrm{C}-\mathrm{H}$ bonds across the $\mathrm{C}=\mathrm{C}$ bond of olefins. The results of several reactions are shown in Table 1. For example, under $25 \mathrm{psi}$ of ethylene pressure, $0.1 \mathrm{~mol} \%$ of $\mathbf{1}$ in benzene $\left(90^{\circ} \mathrm{C}\right)$ catalyzes the formation of ethyl benzene with 51 turnovers after $4 \mathrm{~h}$. Using 0.1 mol \% of $\mathbf{1}$, trace quantities of 1,3- and 1,4-diethylbenzene are produced without detectable quantities of 1,2di ethylbenzene. After $4 \mathrm{~h}$, the rate of catalysis begins to slow; however, 77 turnovers are achieved after $24 \mathrm{~h}$ at $90{ }^{\circ} \mathrm{C}$. Beyond this time, the production of ethylbenzene significantly decreases. Evidence of styrene formation has not been obtained for catalytic reactions of ethylene and benzene using between 0.1 and $1 \mathrm{~mol} \%$ of complex 1 when the ethylene pressure is $\leq 60$ psi. A recent computational study suggested that at high ethylene pressures multiple insertions of ethylene will be observed. ${ }^{44}$ In accord with this prediction, reaction at 250 psi of ethylene pressure produces a small amount of butylbenzene ( $<1$ turnover).

(39) Matsumoto, T.; Taube, D.J .; Periana, R. A.; Taube, H.; Yoshida, H. J. Am. Chem. Soc. 2000, 122, 7414-7415.

(40) Matsumoto, T.; Periana, R. A.; Taube, D.J .; Yoshida, H. J . Mol . Catal. A.: Chem. 2002, 180, 1-18.

(41) Periana, R. A.; Liu, X. Y.; Bhalla, G. Chem. Commun. 2002 24, 3000-3001.

(42) Matsumoto, T.; Y oshida, H. Catal. Lett. 2001, 72, 107-109.

(43) Lail, M.; Arrowood, B. N.; Gunnoe, T. B. J . Am. Chem. Soc 2003, 7506-7507.

(44) Oxgaard, J .; Goddard, W. A., III. J . Am. Chem. Soc. 2004, 126, $442-443$. 
In contrast to Lewis acid-catalyzed Friedel-Crafts reactions, complex $\mathbf{1}$ is mildly selective for linear over branched alkyl benzene product. For example, the reaction of propene and benzene at $25 \mathrm{psi}\left(90^{\circ} \mathrm{C}\right)$ yields a 1.6:1 ratio of linear propyl benzene to cumene. In addition, the formation of trans- $\beta$-methylstyrene is observed in nearly quantitative yield based on complex 1. After $4 \mathrm{~h}$ at $90^{\circ} \mathrm{C}$, catalyst activity ceases. The reaction of 1 -hexene and benzene $\left(90^{\circ} \mathrm{C}, 1 \mathrm{~mol} \%\right.$ of $\left.\mathbf{1}\right)$ results in the production of linear 1-phenyl hexane and branched 2-phenylhexane in a 1.7:1.0 ratio along with formation of trans-1-phenylhex-1-ene. In contrast to an $\operatorname{Ir}(\mathrm{III})$ system that catalyzes similar reactions, ${ }^{42}$ evidence for the isomerization of 1-hexene to internal ol efins has not been obtained for catalysis with complex 1. Accordingly, detectable quantities of 3-phenylhexane are not produced in the catalytic reactions of benzene with 1-hexene. The combination of $0.1 \mathrm{~mol} \%$ of $\mathbf{1}$ in benzene with isobutylene does not yield new organic products after $24 \mathrm{~h}$ at $90{ }^{\circ} \mathrm{C}$. The reaction of benzene and acetylene with $1 \mathrm{~mol} \%$ of $\mathbf{1}$ yields only trace quantities of styrene after $24 \mathrm{~h}$ at $90^{\circ} \mathrm{C}$.

Complex 1 can also catalyze reactions of monoalkylated arenes. For example, the combination of $0.1 \mathrm{~mol}$ $\%$ of $\mathbf{1}$ with ethylbenzene and ethylene results in the formation of 1,3-diethyl benzene and 1,4-diethyl benzene. No evidence for the formation of the ortho disubstituted product 1,2-diethylbenzene is observed. The rate of conversion of ethylbenzene to diethylbenzenes is approximately 7 times slower than the rate of conversion of benzene to ethylbenzene. For example, after $2 \mathrm{~h}$ at $90{ }^{\circ} \mathrm{C}$ with $0.1 \mathrm{~mol} \%$ of $\mathbf{1}, 43$ turnovers of benzene to ethylbenzene are observed. For the identical reaction in ethylbenzene, after $2 \mathrm{~h}$ a total of approximately 6 turnovers to 1,3- and 1,4-di ethyl benzene are observed.

We have previously reported that TpRu(II ) complexes catalyze radical polymerization reactions of electrondeficient ol efins. ${ }^{45}$ Thus, efficient catalytic hydroarylation reactions of olefins such as methyl methacrylate, styrene, or acrylonitrile are not possible due to radical polymerization side reactions. Attempted hydrophenylation of methylvinyl ketone resulted in a previously reported thermal cyclodimerization reaction. ${ }^{46}$

Simple Lewis acids are known to catalyze the net addition of arene $\mathrm{C}-\mathrm{H}$ bonds across ol efin $\mathrm{C}=\mathrm{C}$ bonds by activating the ol efin toward carbocationic reactivity (i.e., el ectrophilic additi on to the arene). ${ }^{6,7}$ However, the Ru-catalyzed reactions exhibit characteristics that are inconsistent with classic Friedel-Crafts chemistry. The primary evidence against the $\mathrm{TpRu}(\mathrm{II})$ complex acting as a Friedel-Crafts catalyst is the mildly selective production of linear over branched products in the reactions of benzene with the $\alpha$-olefins propene and 1-hexene. In addition, F riedel-Crafts reactions typically produce 1,2-dial kyl products in addition to 1,3- and 1,4dialkyl benzenes. TpRu(CO)(NCMe)(Ph) (1) does not produce 1,2-di ethyl benzene in detectable quantity during the reaction of ethylene with ethyl benzene. Presumably, the lack of formation of 1,2-diethylbenzene using complex $\mathbf{1}$ as catalyst is due to steric selectivity in the metal-mediated $\mathrm{C}-\mathrm{H}$ activation step (see bel ow) si milar

(45) Arrowood, B. N.; Lail, M.; Gunnoe, T. B.; Boyle, P. D. Organometallics 2003, 22, 4692-4698.

(46) J enner, G.; Rimmelin, J .; Libs, S.; Antoni, F. Tetrahedron 1976 $32,1107-1111$.

\section{Scheme 1. Proposed Catalytic Cycle for the Addition of Benzene to Olefins (ethylene shown)}

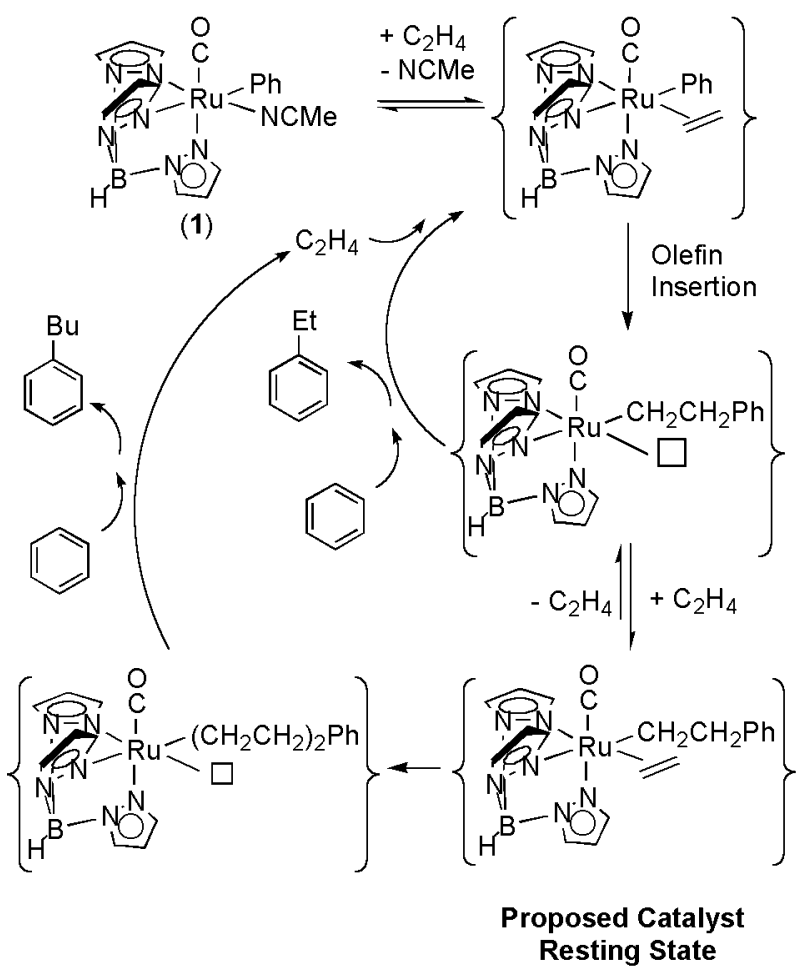

to that directly observed in stoichiometric aromatic $\mathrm{C}-\mathrm{H}$ oxidative addition reactions..$^{47}$ Heating $\left(90^{\circ} \mathrm{C}\right)$ a $1: 1$ molar mixture of 1,4-diethylbenzene and benzene in the presence of $\mathbf{1}$ does not result in the formation of ethylbenzene (after $24 \mathrm{~h}$ ) as is often observed for F riedel-Crafts catalysts. The relative rate of reaction of benzene versus monoalkylated benzene is contrary to observations made for most Lewis acid-catalyzed Friedel-Crafts reactions. For example, catalytic addition of $\mathrm{C}-\mathrm{H}$ bonds to ethylene using $\mathbf{1}$ as catalyst is approximately 7 times more rapid for benzene than ethylbenzene (based on analysis after $2 \mathrm{~h}$ of reaction). Finally, the lack of catalytic activity for $\mathrm{TpRu}(\mathrm{CO})_{2}(\mathrm{Me})$, a precursor to complex $\mathbf{1}$, indicates that minor amounts of impurities from commercial starting reagents are not responsible for the catalysis.

Proposed Catalytic Cycle. A proposed catalytic cycle is shown in Scheme 1 using ethylene as the ol efinic substrate. The first step in the proposed cycle involves dissociation of acetonitrile. Heating a $\mathrm{CDCl}_{3}$ solution of $1 \mathrm{in}$ the presence of $\mathrm{CD}_{3} \mathrm{CN}$ results in a decrease in the intensity of the resonance ( ${ }^{1} \mathrm{H}$ NMR) of the coordinated $\mathrm{NCCH}_{3}$ and the appearance of a singlet consistent with free $\mathrm{NCCH}_{3}$. In $\mathrm{CD}_{3} \mathrm{CN}$ at $90{ }^{\circ} \mathrm{C}$ the exchange reaction has a half-life of approximately $15 \mathrm{~min}$. The ability of the acetonitrile ligand to undergo exchange suggests that proposed ethylene/acetonitrile ligand exchange is feasible under catalytic conditions (Scheme 1). The lack of catalysis with disubstituted ol efins (e.g., isobutylene) is likely explained by steric inhibition of ol efin coordination in this first step.

Insertion of ethyleneinto the Ru-phenyl bond (second step in the proposed catalytic cycle) provides a pathway for $\mathrm{C}-\mathrm{C}$ bond formation. Direct evidence for ol efin

(47) J ones, W. D.; Feher, F. J . J . Am. Chem. Soc. 1982, 104, 4240- 


\section{Scheme 2. Orientation of the Olefin $\mathrm{C}=\mathrm{C}$ Bond Parallel to the $R \mathbf{u}-\mathbf{P h}$ Bond Optimizes d $\pi$-Back-Bonding}

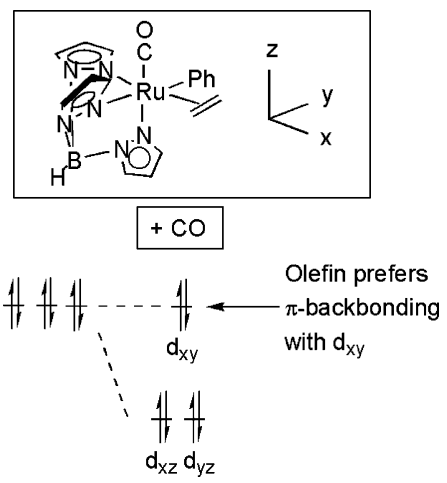

insertion has been obtained from the isolation of TpRu(CO)(NCMe) $\left(\mathrm{CH}_{2} \mathrm{CH}_{2} \mathrm{Ph}\right)(2)$ in approximately $50 \%$ yield upon reaction of $\mathrm{TpRu}(\mathrm{CO})(\mathrm{NCMe})(\mathrm{Ph})$ with ethylene (250 psi) in acetonitrile (eq 1). TpRu(CO)( $\mathrm{NCMe})\left(\mathrm{CH}_{2-}\right.$

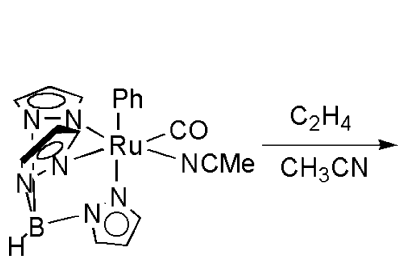

(1)

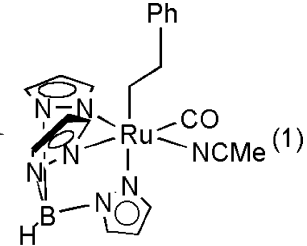

(2)
$\mathrm{CH}_{2} \mathrm{Ph}$ ) (2) has been independently prepared and characterized (see below).

For the putative complex TpRu(CO)(Ph)( $\eta^{2}$-olefin) that precedes the insertion step, the presence of the strong $\pi$-acid CO likely results in a preferred ol efin orientation in which the $\mathrm{C}=\mathrm{C}$ bond is parallel to the $\mathrm{Ru}$-phenyl bond. In the proposed olefin orientation, which is supported by DFT calculations (see below), $\pi$-back-bonding interactions are optimized (Scheme 2), and the $\mathrm{C}=\mathrm{C}$ bond is aligned for the subsequent insertion step. Insertions of olefins into late transition metal-aryl bonds have precedent. For example, the Heck reaction involves alkene insertion into $\mathrm{Pd}$-aryl bonds as a key reaction step..$^{8,9}$ In addition, stoichiometric ethylene insertion into Ru(II) phenyl bonds and $\mathrm{Ru}$ (II )-catalyzed Heck reactions have been reported. ${ }^{48-52}$ For $\alpha$-olefins, the regioselectivity of olefin insertion would determine the selectivity of branched versus linear alkyl arene products, and the observed selectivity for linear over branched alkyl arenes suggests that 2,1insertion (product I in Scheme 3) is slightly favored.

A computational study by Oxgaard and Goddard suggests that the regioselectivity of $\alpha$-olefin insertion for $\mathrm{TpRu}(\mathrm{CO})(\mathrm{Ph})\left(\eta^{2}-\mathrm{H}_{2} \mathrm{C}=\mathrm{C}(\mathrm{H}) \mathrm{Me}\right)$ is controlled by steric interactions between the alkyl group of the ol efin and pyrazolyl rings. ${ }^{44}$ The linear-to-branched ratios for

(48) Faller, J . W.; Chase, K. J . Organometallics 1995, 14, 15921600.

(49) Ritleng, V.; Pfeffer, M.; Sirlin, C. Organometallics 2003, 22 347-354.

(50) Ritleng, V.; Sutter, J . P.; Pfeffer, M.; Sirlin, C. Chem. Commun. 2000.

(51) Farrington, E. J .; Brown, J . M.; Barnard, C. F. J .; Rowsell, E. Angew. Chem. Int. Ed. 2002, 41, 169-171.

(52) Na, Y.; Park, S.; Han, S. B.; Han, H.; Ko, S.; Chang, S. J . Am. Chem. Soc. 2004, 126, 250-258.

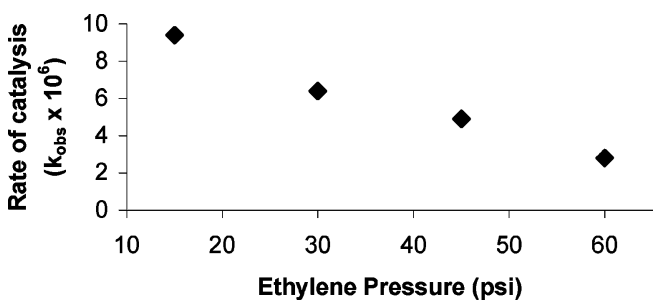

Figure 1. Dependence of the rate of catalysis on ethylene pressure for the addition of benzene to ethylene $(0.1 \mathrm{~mol}$ $\%$ of $\mathbf{1}, 70^{\circ} \mathrm{C}$ ).

\section{Scheme 3. Regioselectivity of Olefin Insertion Likely Dictates the Linear to Branched Selectivity for the Hydrophenylation of $\alpha$-Olefins}
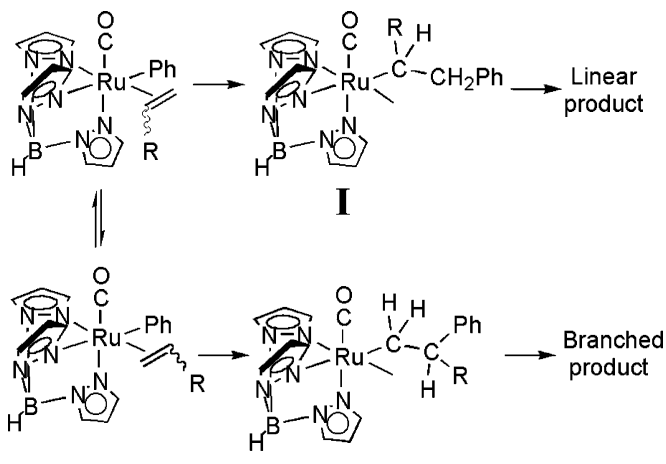

II

the hydrophenylation of propene and 1-hexene catalyzed by Ir(III) are nearly identical to that using complex $\mathbf{1}$ as catalyst. ${ }^{40}$ However, the regiosel ectivity of propene hydrophenylation mediated by $\mathrm{CpRu}\left(\mathrm{PPh}_{3}\right)_{2}(\mathrm{Ph})$ of $5: 1$ (linear:branched ratio, see below) indicates that the similarity between the Ir(III) catalyst and TpRu(CO)$(\mathrm{NCMe})(\mathrm{Ph})(\mathbf{1})$ is likely coincidental rather than implicating that electronic factors during insertion dictate the selectivity. Heck reactions involving the insertion of $\alpha$-ol efins with alkyl substituents into $\mathrm{Pd}-\mathrm{Ph}$ bonds, as well as Ru-catalyzed Heck reactions that incorporate acrylates, are selective for 2,1-insertion. ${ }^{51-53}$

Ethylene insertion into the Ru-phenyl bond of TpRu(CO) $\left(\eta^{2}-\mathrm{H}_{2} \mathrm{C}=\mathrm{CH}_{2}\right)(\mathrm{Ph})$ creates an open coordination site that can bind ethylene to yield the proposed catalyst resting state TpRu(CO) $\left(\eta^{2}-\mathrm{H}_{2} \mathrm{C}=\mathrm{CH}_{2}\right)\left(\mathrm{CH}_{2} \mathrm{CH}_{2} \mathrm{Ph}\right)$. The formation of butylbenzene at high ethylene pressure (250 psi, see above) indicates that a second insertion of ethylene is competitive with arene $\mathrm{C}-\mathrm{H}$ activation under conditions that increase the concentration of the putative catalyst resting state $\mathrm{TpRu}(\mathrm{CO})\left(\eta^{2}-\mathrm{H}_{2} \mathrm{C}=\mathrm{CH}_{2}\right)$ $\left(\mathrm{CH}_{2} \mathrm{CH}_{2} \mathrm{Ph}\right)$. Between 15 and 60 psi of ethylene, the rate of catalytic addition of benzene to ethylene de creases with increasing ethylene pressure (Figure 1 ), and the inhibition of catalysis upon increasing ethylene pressure is consistent with $\mathrm{TpRu}(\mathrm{CO})\left(\eta^{2}-\mathrm{H}_{2} \mathrm{C}=\mathrm{CH}_{2}\right)\left(\mathrm{CH}_{2-}\right.$ $\left.\mathrm{CH}_{2} \mathrm{Ph}\right)$ as the catalyst resting state. Deriving a rate law for the proposed steps in catalytic $\mathrm{C}-\mathrm{H}$ activation (Scheme 4, $\mathrm{L}=$ ethylene) yiel ds eq 2. If $\mathrm{k}_{-1}\left[\mathrm{C}_{2} \mathrm{H}_{4}\right]>\mathrm{k}_{2}$ -

$$
\text { Rate }=\frac{\mathrm{k}_{1} \mathrm{k}_{2}[\mathrm{Ru}]\left[\mathrm{C}_{6} \mathrm{H}_{6}\right]}{\mathrm{k}_{-1}\left[\mathrm{C}_{2} \mathrm{H}_{4}\right]+\mathrm{k}_{2}\left[\mathrm{C}_{6} \mathrm{H}_{6}\right]}
$$

$\left[\mathrm{C}_{6} \mathrm{H}_{6}\right]$, then the reaction rate should exhibit an inverse first-order dependence on ethylene concentration. Similar to the hydrophenylation of ethylene using $\mathbf{1}$ as catalyst, an inverse dependence on ethylene pressure 


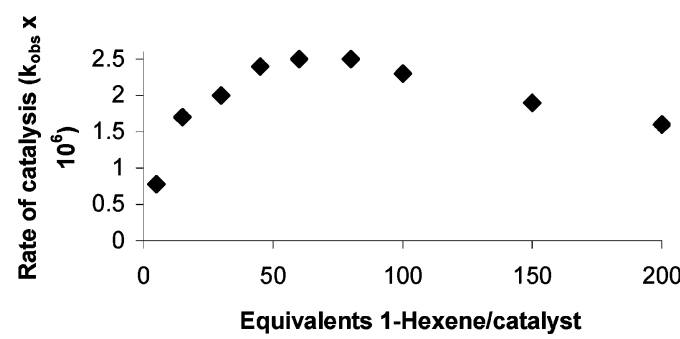

Figure 2. Dependence of the rate of benzene addition to 1-hexene on concentration of 1-hexene $(0.1 \mathrm{~mol} \%$ of $\mathbf{1}, 70$ $\left.{ }^{\circ} \mathrm{C}\right)$

\section{Scheme 4. Proposed Pathway for Benzene $\mathbf{C}-\mathrm{H}$ Activation by $\mathrm{TpRu}(\mathrm{CO})(\mathrm{R})(\mathrm{L})(\mathrm{R}=\mathrm{Me}$ or $\mathrm{CH}_{2} \mathrm{CH}_{2} \mathrm{Ph}$ and $\mathrm{L}=\mathrm{NCMe}$ or ethylene)}

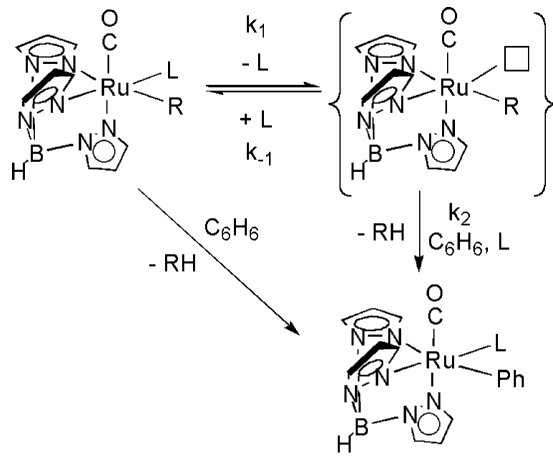

has been reported for I r-catalyzed formation of ethylbenzene at high ethylene/benzene ratios. ${ }^{40}$ Unfortunately, attempts to isolate the proposed catalyst resting state have failed. Monitoring a catalytic reaction at 20 psi of ethylene in an NMR tube reaction allows observation of a new TpRu system that exhibits resonances consistent with the proposed resting state; however, the presence of the catalytic precursor, ethylbenzene, and catalyst decomposition make definitive assignment of this complex difficult.

For catalytic reactions of 1-hexene/benzene using complex 1, at low 1-hexene concentrations the rate of catalysis increases with increasing concentration of 1-hexene; however, the reaction rate reaches an apex at approximately 80 equiv (based on 1) of 1-hexene. Beyond this point, increasing the concentration of 1-hexene results in a decrease in the rate of catalysis (Figure 2). These results suggest that at low concentrations of 1-hexene the catalyst resting state is $\mathrm{TpRu}(\mathrm{CO})$ (NCMe)(Ph) (1), and IR spectroscopy of a catalytic reaction in progress reveals a $\mathrm{CO}$ absorption identical to that of complex $\mathbf{1}$. At higher concentrations of 1-hexene, the catalyst resting state likely shifts to TpRu$(\mathrm{CO})\left(\eta^{2}-\mathrm{H}_{2} \mathrm{C}=\mathrm{C}(\mathrm{Bu}) \mathrm{H}\right)(\mathrm{R})(\mathrm{R}=$ hexylphenyl isomers $)$.

The final step of the proposed catalytic cycle is Rumediated $\mathrm{C}-\mathrm{H}$ activation with release of alkyl benzene, and the proposed metal-mediated $\mathrm{C}-\mathrm{H}$ activation is consistent with the assertion that the reaction proceeds via a non-Friedel Crafts mechanism. Performing the catalytic addition of $\mathrm{C}_{6} \mathrm{D}_{6}$ to ethylene $\left(\mathrm{C}_{2} \mathrm{H}_{4}\right)$ using complex 1 results in the formation of $d_{5}-\mathrm{PhCH}_{2} \mathrm{CH}_{2} \mathrm{D}$ as indicated by ${ }^{1} \mathrm{H}$ NMR spectroscopy and mass spectrometry (eq 3). For example, the ${ }^{1} \mathrm{H}$ NMR spectrum of the catalyst solution $\left(\mathrm{C}_{6} \mathrm{D}_{6}\right)$ after $12 \mathrm{~h}$ at $70^{\circ} \mathrm{C}$ reveals

(53) Heck, R. F. In Organic Reactions; Duaben, W. G., Ed.; J ohn Wiley and Sons: New York, 1982; Vol. 27, pp 345-390.

\section{Scheme 5. Catalytic Hydroarylation of Ethylene $\left(\mathrm{C}_{2} \mathrm{H}_{4}\right)$ in a 1:1 Ratio of $\mathrm{C}_{6} \mathrm{H}_{6}$ and $\mathrm{C}_{6} \mathrm{D}_{6}$ Produces Isotopic Distributions Based on the Relative Rate of $\mathrm{C}-\mathrm{H}$ and $\mathrm{C}-\mathrm{D}$ Bond Activation of Benzene}

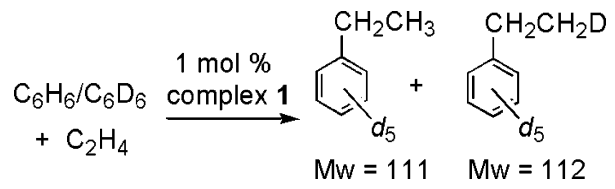

a multiplet at $1.1 \mathrm{ppm}$ due to the monodeuterated methyl group of $\mathrm{d}_{6}$-ethylbenzene as well as a triplet of triplets $\left(\mathrm{JHH}_{\mathrm{HH}} \approx 7 \mathrm{~Hz}\right.$ and $\mathrm{J} \mathrm{HD} \approx 1 \mathrm{~Hz}$ ) at 2.4 ppm due to the methylene group. In addition, approximately 1 equiv (based on concentration of $\mathbf{1}$ ) of $\mathrm{PhCH}_{2} \mathrm{CH}_{2} \mathrm{D}$ is formed due to the protio-phenyl group of the catalyst $\mathbf{1}$.

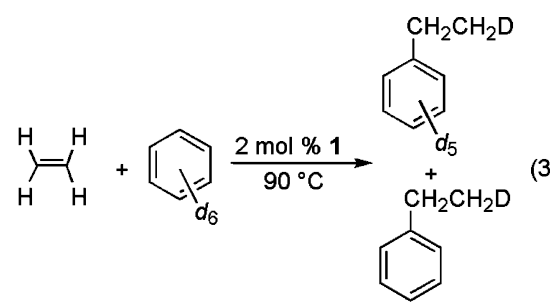

Additional evidence of the ability of $\{\mathrm{TpRu}(\mathrm{CO})(\mathrm{R})\}$ $(\mathrm{R}=$ alkyl) fragments to initiate arene $\mathrm{C}-\mathrm{H}$ activation comes from the stoichiometric reaction of $\mathrm{TpRu}(\mathrm{CO})$ (Me)(NCMe) with benzene. In the presence of acetonitrile, the reaction of $\mathrm{TpRu}(\mathrm{CO})(\mathrm{Me})(\mathrm{NCMe})$ with benzene produces TpRu(CO)(NCMe)(Ph) (1) and methane. The formation of methane via $\mathrm{C}-\mathrm{H}$ activation of benzene is confirmed by the observation of $\mathrm{CH}_{3} \mathrm{D}$ in reactions performed in sealed NMR tubes using $\mathrm{C}_{6} \mathrm{D}_{6}$ (eq 4). The complex $\mathrm{TpRu}\left(\mathrm{PPh}_{3}\right)(\mathrm{NCMe})(\mathrm{H})$ has been re

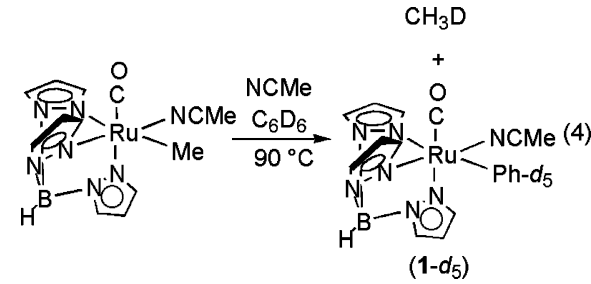

ported to initiate H/D exchange between methane and deuterated solvents. ${ }^{54}$ The rate of conversion of TpRu(CO)(Me)(NCMe) and benzene to complex $\mathbf{1}$ and methane is suppressed by increasing the concentration of acetonitrile. ${ }^{43}$ Thus, access to the coordinatively unsaturated fragment $\{\mathrm{TpRu}(\mathrm{CO})(\mathrm{R})\}(\mathrm{R}=$ alkyl) is apparently necessary for benzene $\mathrm{C}-\mathrm{H}$ activation (Scheme 4).

A kinetic isotope effect (KIE) was determined by analysis of reaction products from a catalytic reaction of ethylene in a $1: 1$ ratio of $\mathrm{C}_{6} \mathrm{H}_{6}$ and $\mathrm{C}_{6} \mathrm{D}_{6}$. The possible isotopic distributions of products and their molecular weights are shown in Scheme 5. Comparison of the ratios of peaks due to $M_{w} 112 / 111$ all ows a determination of the kinetic isotope effect for the carbon-hydrogen bond-breaking step. The ratio reveals a kinetic selectivity for $\mathrm{C}-\mathrm{H}$ activation over $\mathrm{C}-\mathrm{D}$ activation by 2.1(1).

A control experiment using a $1: 1$ mixture of $\mathrm{C}_{6} \mathrm{H}_{6} /$ $\mathrm{C}_{6} \mathrm{D}_{6}$ in the presence of $1 \mathrm{~mol} \%$ of complex $\mathbf{1}$ (in

(54) Ng, S. M.; Lam, W. H.; Mak, C. C.; Tsang, C. W.; J ia, G.; Lin Z.; Lau, C. P. Organometallics 2003, 22, 641-651. 
the absence of ethylene) at $90{ }^{\circ} \mathrm{C}$ reveals isotopic scrambling in the benzene. For example, after $2 \mathrm{~h}$ the ratio of molecular weight $78 / 79\left(\mathrm{C}_{6} \mathrm{H}_{6} / \mathrm{C}_{6} \mathrm{H}_{5} \mathrm{D}\right)$ decreased by $30 \%$. During the same time period, the ratio of $\mathrm{C}_{6} \mathrm{D}_{6} /$ $\mathrm{C}_{6} \mathrm{D}_{5} \mathrm{H}$ undergoes an analogous change. These results indicate that the $\mathrm{Ru}(\mathrm{II})$ phenyl complex $\mathbf{1}$ catalyzes isotopic scrambling between $\mathrm{C}_{6} \mathrm{H}_{6}$ and $\mathrm{C}_{6} \mathrm{D}_{6}$ (the abundance of other mixed isotopomers al so increases). However, monitoring the ratios of peaks due to molecular weights 78/79 $\left(\mathrm{C}_{6} \mathrm{H}_{6} / \mathrm{C}_{6} \mathrm{H}_{5} \mathrm{D}\right)$ and 84/85 $\left(\mathrm{C}_{6} \mathrm{D}_{5} \mathrm{H} / \mathrm{C}_{6} \mathrm{D}_{6}\right)$ during the catalytic reaction reveals that isotope scrambling between $\mathrm{C}_{6} \mathrm{H}_{6}$ and $\mathrm{C}_{6} \mathrm{D}_{6}$ under ethylene pressure (25 psi) is negligible. The significant reduction in the extent of isotopic scrambling between $\mathrm{C}_{6} \mathrm{H}_{6}$ and $\mathrm{C}_{6} \mathrm{D}_{6}$ in the presence of ethylene indicates that monitoring the molecular weights of ethylbenzene products under catalytic conditions provides a reliable method to approximate the KIE for the catalytic reaction.

It is anticipated that the kinetic isotope effect for the catalytic reaction should be similar to the kinetic isotope effect for benzene $\mathrm{C}-\mathrm{H}$ activation by $\mathrm{TpRu}(\mathrm{CO})(\mathrm{Me})$ (NCMe) to produce methane and $\mathrm{TpRu}(\mathrm{CO})(\mathrm{Ph})(\mathrm{NCMe})$. The reaction of $\mathrm{TpRu}(\mathrm{CO})(\mathrm{Me})(\mathrm{NCMe})$ in a 1:1 molar mixture of $\mathrm{C}_{6} \mathrm{H}_{6}$ and $\mathrm{C}_{6} \mathrm{D}_{6}$ in a gastight $\mathrm{NMR}$ tube at $90{ }^{\circ} \mathrm{C}$ for $30 \mathrm{~min}$ produces resonances for both $\mathrm{CH}_{4}$ and $\mathrm{CH}_{3} \mathrm{D}$ (eq 5). Integration of these two resonances reveals

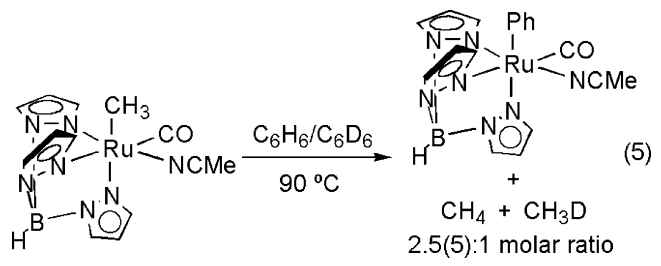

a kinetic isotope effect of 2.5(5). The large deviation is due, in part, to the poor signal-to-noise that results from the necessity of analyzing the reaction before significant isotopic scrambling. GC-MS of the reaction solution after $30 \mathrm{~min}$ of reaction reveals that approximately $10 \%$ of the $\mathrm{C}_{6} \mathrm{H}_{6}$ and the $\mathrm{C}_{6} \mathrm{D}_{6}$ have undergone isotopic scrambling. Although analysis at longer time periods would improve signal-to-noise of the resonances due to methane, isotopic scrambl ing would complicate analysis of the KIE. Even though the isotopic scrambling after 30 min of reaction does not allow a quantitative determination of the KIE, the KIEs for the stoichiometric benzene $\mathrm{C}-\mathrm{H}$ activation by $\mathrm{TpRu}(\mathrm{CO})(\mathrm{NCMe})(\mathrm{Me})$ and the catalytic hydrophenylation of ethylene are identical within deviation.

Study of $\boldsymbol{\beta}$-Hydride Elimination. The previously reported dicarbonyl complex $\left[\mathrm{TpRu}(\mathrm{CO})_{2}(\mathrm{THF})\right]\left[\mathrm{PF}_{6}\right]$ reacts with $\mathrm{PhCH}_{2} \mathrm{CH}_{2} \mathrm{MgCl}$ to yield $\mathrm{TpRu}(\mathrm{CO})_{2}\left(\mathrm{CH}_{2}-\right.$ $\mathrm{CH}_{2} \mathrm{Ph}$ ) (3) (eq 6). ${ }^{55}$ Complex $\mathbf{3}$ has been characterized

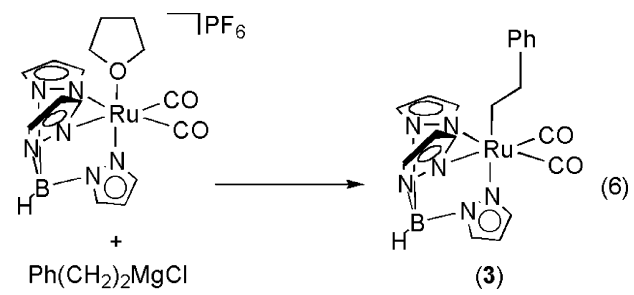

by IR and ${ }^{1} \mathrm{H}$ and ${ }^{13} \mathrm{C} \mathrm{NMR}$ spectroscopy with $v_{\mathrm{CO}}=$ 2025 and $1954 \mathrm{~cm}^{-1}$ (IR spectrum), methylene reso-

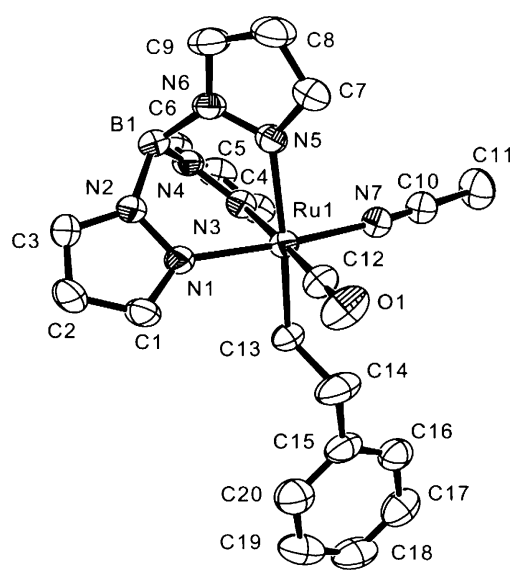

Figure 3. ORTEP of TpRu(CO)(NCMe) $\left(\mathrm{CH}_{2} \mathrm{CH}_{2} \mathrm{Ph}\right)$ (2) ( $30 \%$ probability with hydrogen atoms omitted). Selected bond lengths $(\AA)$ : $\mathrm{Ru}-\mathrm{N} 7,2.020(3) ; \mathrm{Ru}-\mathrm{C} 13,2.115(4) ; \mathrm{Ru}-$ $\mathrm{N1}$ 2.062(3); Ru-N3, 2.138(3); Ru-N5, 2.191(3); Ru-C12, 1.819(4); N7-C10, 1.128(5); C13-C14, 1.474(6); C14-C15, 1.521(7). Selected bond angles (deg): Ru-C13-C14, 119.0(3); $\mathrm{Ru}-\mathrm{N} 7-\mathrm{C} 10,170.6(3) ; \mathrm{Ru}-\mathrm{C} 12-\mathrm{O} 1,179.2(4) ; \mathrm{C} 12-\mathrm{Ru}-$ $\mathrm{C} 13,90.85(16) ; \mathrm{N} 1-\mathrm{Ru}-\mathrm{N} 3,84.95(12) ; \mathrm{N} 1-\mathrm{Ru}-\mathrm{N} 5,86.71(12) ;$ N3-Ru-N5, 83.90(11); C13-Ru-N7, 88.94(14).

\section{Table 2. Selected Crystallographic Data and Collection Parameters for $\mathrm{TpRu}(\mathrm{CO})(\mathrm{NCMe})\left(\mathrm{CH}_{2} \mathrm{CH}_{2} \mathrm{Ph}\right)$ (2)}

empirical formula
fw
cryst syst
space group
a, $\AA$
b, $\AA$
C, $\AA$
$\alpha$, deg
$\beta$, deg
$\gamma$, deg
V $\left(\AA^{3}\right)$
$Z$
Dcalcd, $g \mathrm{~cm}^{-3}$
R1, wR2 $(I>2 \sigma(I))$
GOF

$\mathrm{C}_{20} \mathrm{H}_{22} \mathrm{BN}_{7} \mathrm{ORu}$ 488.33 monoclinic $\mathrm{P} 2 / \mathrm{C}$ $11.6082(9)$ $12.2077(10)$ $15.9446(14)$ 90 $92.715(2)$ 90 2257.0(3) 4 1.437 $0.0455,0.1054$ 1.020

nances at 3.38 and 1.93 ppm $\left({ }^{1} \mathrm{H}\right.$ NMR), and ${ }^{1} \mathrm{H} /{ }^{13} \mathrm{C}$ NMR spectra consistent with $\mathrm{C}_{\mathrm{s}}$ molecular symmetry. Oxidative removal of a carbonyl ligand from complex $\mathbf{3}$ upon addition of $\mathrm{Me}_{3} \mathrm{NO}$ in refluxing acetonitrile yields the monocarbonyl product TpRu(CO)(NCM e) $\left(\mathrm{CH}_{2} \mathrm{CH}_{2-}\right.$ $\mathrm{Ph}$ ) (2) (eq 7). The conversion of $\mathbf{3}$ to $\mathbf{2}$ is characterized

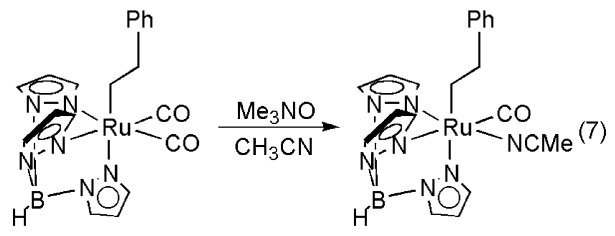

(3)

(2)

by the disappearance of the $\mathrm{CO}$ stretching absorptions due to $\mathbf{3}$ and the appearance of a single $\mathrm{CO}$ absorption at $1917 \mathrm{~cm}^{-1}$. Complex $\mathbf{2}$ has been characterized by a single-crystal X-ray diffraction study. The ORTEP of $\mathbf{2}$ is displayed in Figure 3 , and data collection parameters are listed in Table 2 . The structure reveals an asymmetric complex with an approximately octahedral coordination sphere. The Ru-alkyl carbon bond distance is $2.115(4) \AA$.

(55) Sørlie, M.; Tilset, M. Inorg. Chem. 1995, 34, 5199-5204. 
Scheme 6. Proposed Reaction Pathway for the Conversion of $\mathrm{TpRu}(\mathrm{CO})(\mathrm{NCMe})\left(\mathrm{CH}_{2} \mathrm{CH}_{2} \mathrm{Ph}\right)$ (2) to $\mathrm{TpRu}(\mathrm{CO})(\mathrm{NCMe})(\mathrm{Cl})(4)$

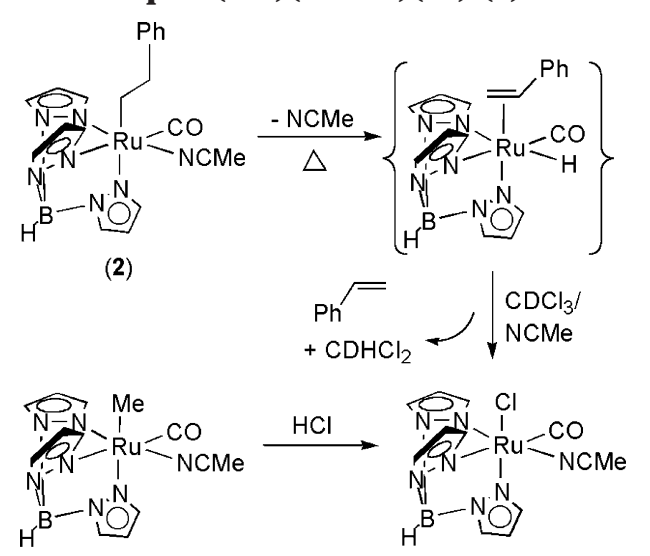

(4)

Consistent with the proposed catalytic pathway (Scheme 1), the reaction of complex 2 with $\mathrm{C}_{6} \mathrm{D}_{6}$ at 90 ${ }^{\circ} \mathrm{C}$ results in the production of $\mathrm{PhCH}_{2} \mathrm{CH}_{2} \mathrm{D}$ and TpRu$(\mathrm{CO})(\mathrm{NCMe})\left(\mathrm{Ph}-\mathrm{d}_{5}\right)\left(\mathbf{1}-\mathrm{d}_{5}\right)$ as determined by ${ }^{1} \mathrm{H}$ NMR spectroscopy (eq 8). In addition, the combination of 1

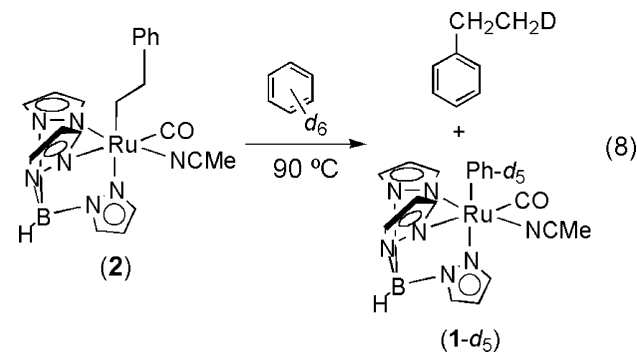

mol $\%$ of $\mathbf{2}$ in benzene under 25 psi $\left(90^{\circ} \mathrm{C}\right)$ results in the catalytic production of ethylbenzene.

The proposed reaction mechanism for the addition of benzene to ethylene involves the formation of the coordinatively unsaturated $\left\{\mathrm{TpRu}(\mathrm{CO})\left(\mathrm{CH}_{2} \mathrm{CH}_{2} \mathrm{Ph}\right)\right\}$ system that would likely be susceptible to a $\beta$-hydride elimination reaction to produce $\mathrm{TpRu}(\mathrm{CO})(\mathrm{H})\left(\eta^{2}\right.$-styrene); however, styrene formation is not observed during catalytic hydrophenylation reactions of ethylene at ethylene pressures up to $60 \mathrm{psi}$. The lack of observation of styrene indicates that either $\beta$-hydride elimination is not kinetically competitive or that dissociation of styrene from $\mathrm{TpRu}(\mathrm{CO})(\mathrm{H})\left(\eta^{2}\right.$-styrene) has a substantial activation barrier (i.e., $\beta$-hydride elimination is reversible). We sought to explore $\beta$-hydride el imination from the putative intermediate $\left\{\mathrm{TpRu}(\mathrm{CO})\left(\mathrm{CH}_{2} \mathrm{CH}_{2} \mathrm{Ph}\right)\right\}$ in more detail using $\mathrm{TpRu}(\mathrm{CO})(\mathrm{NCMe})\left(\mathrm{CH}_{2} \mathrm{CH}_{2} \mathrm{Ph}\right)$ (2). Heating $\left(70^{\circ} \mathrm{C}\right)$ a $\mathrm{CDCl}_{3}$ solution of $\mathrm{TpRu}(\mathrm{CO})(\mathrm{NCMe})$ $\left(\mathrm{CH}_{2} \mathrm{CH}_{2} \mathrm{Ph}\right)$ results in the quantitative production (by ${ }^{1} \mathrm{H}$ NMR spectroscopy) of styrene, $\mathrm{CHDCl}_{2}$, and $\mathrm{TpRu}$ (CO)(NCMe)(Cl) (4) after 30 min. Complex 4 has been independently prepared upon reaction of $\mathrm{HCl}$ with $\mathrm{TpRu}(\mathrm{CO})(\mathrm{NCMe})(\mathrm{Me})$ (Scheme 6). The formation of $\mathbf{4}$ likely occurs via $\beta$-hydride elimination to produce $\left\{\mathrm{TpRu}(\mathrm{CO})(\mathrm{H})\left(\eta^{2}\right.\right.$-styrene) $\}$ followed by dissociation of styrene and conversion of the $\mathrm{Ru}-\mathrm{H}$ bond to a $\mathrm{Ru}-\mathrm{Cl}$ bond upon reaction with $\mathrm{CDCl}_{3}$ (regardless of reaction order; Scheme 6). The rapid conversion of complex $\mathbf{2}$ to complex $\mathbf{4}$ indicates that $\beta$-hydride elimination is kinetically facile, and we attribute the lack of observation of
Scheme 7. $\beta$-Hydride Elimination Transformations for $\operatorname{TpRu}(\mathrm{CO})(\mathrm{L})(\mathrm{R})$ Systems
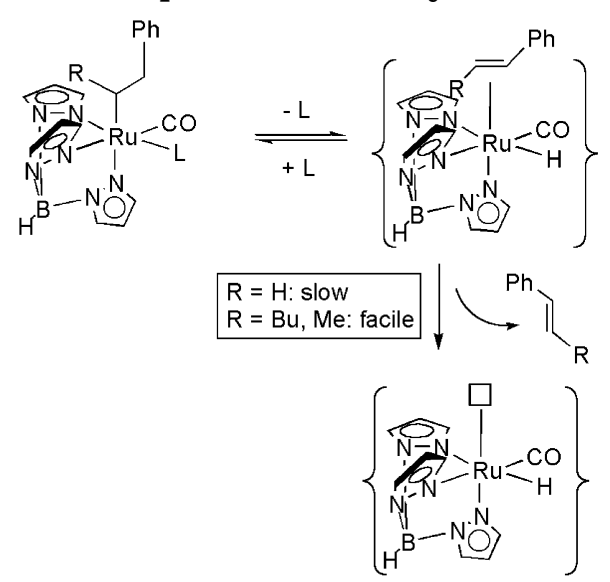

styrene in catalytic ethylene hydrophenylation reactions to reversible $\beta$-hydride elimination. In $\mathrm{CDCl}_{3}$, TpRu$(\mathrm{CO})(\mathrm{H})\left(\eta^{2}\right.$-styrene) is likely trapped by the chlorinated solvent; however, attempts to prepare and isolate TpRu$(\mathrm{CO})(\mathrm{H})\left(\eta^{2}\right.$-styrene) have failed. The observations of trans-1-phenylhex-1-ene and trans- $\beta$-methylstyrene during the hydrophenylation of 1-hexene and propene, respectively, are likely attributable to more facile dissociation of the disubstituted olefins that are formed from $\beta$-hydride elimination (Scheme 7).

Reactions of $\mathrm{CpRu}\left(\mathrm{PPh}_{3}\right)_{2}(\mathrm{Ph})$ and (PCP)Ru(CO)(Ph). To study the generality of the catalytic reactions, we have begun to synthesize and expl ore the catalytic properties of cl osely related Ru(II ) systems. It has previously been reported that $\mathrm{CpRu}\left(\mathrm{PPh}_{3}\right)_{2}(\mathrm{Me})(\mathrm{Cp}$ = cyclopentadienyl) undergoes an intramolecular $\mathrm{C}-\mathrm{H}$ activation at $90{ }^{\circ} \mathrm{C}$ to yield the orthometalated product $\mathrm{CpRu}\left(\mathrm{PPh}_{3}\right)\left(\kappa^{2}-\mathrm{P}, \mathrm{C}-\mathrm{Ph}_{2} \mathrm{PC}_{6} \mathrm{H}_{4}\right)$ and methane. ${ }^{56,57} \mathrm{CpRu}-$ $\left(\mathrm{PPh}_{3}\right)_{2}(\mathrm{Me})$ is isoel ectronic with $\mathrm{TpRu}(\mathrm{CO})(\mathrm{NCMe})(\mathrm{Me})$, and loss of phosphine from $\mathrm{CpRu}\left(\mathrm{PPh}_{3}\right)_{2}(\mathrm{Me})$ complex provides the coordinatively unsaturated complex $\{\mathrm{CpRu}$ $\left.\left(\mathrm{PPh}_{3}\right)(\mathrm{Me})\right\}$, which is isoelectronic to the proposed $\mathrm{TpRu}(\mathrm{II})$ species that initiates arene $\mathrm{C}-\mathrm{H}$ activation. At $70{ }^{\circ} \mathrm{C}, \mathrm{CpRu}\left(\mathrm{PPh}_{3}\right)_{2}(\mathrm{Me})$ reacts with benzeneto yiel d the previously reported phenyl complex $\mathrm{CpRu}\left(\mathrm{PPh}_{3}\right)_{2^{-}}$ (Ph) and methane (eq 9). ${ }^{58}$ The formation of methane

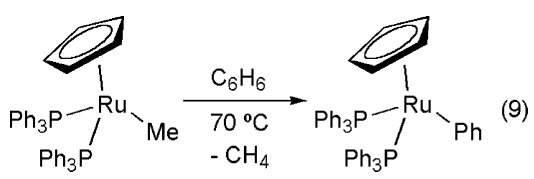

is confirmed by resonances consistent with $\mathrm{CH}_{3} \mathrm{D}$ upon reaction of $\mathrm{CpRu}\left(\mathrm{PPh}_{3}\right)_{2}(\mathrm{Me})$ with $\mathrm{C}_{6} \mathrm{D}_{6}$ in a sealed $\mathrm{NMR}$ tube. Dissolution of $\mathrm{CpRu}\left(\mathrm{PPh}_{3}\right)_{2}(\mathrm{Ph})$ in benzene under $25 \mathrm{psi}$ of ethylene at $90{ }^{\circ} \mathrm{C}$ results in the production of ethylbenzene; however, the reaction is not catalytic, as only 0.12 equiv of ethylbenzene is produced per equivalent of ruthenium. The formation of styrene in 31\% yield is also observed for the CpRu(II) system (eq 10). The

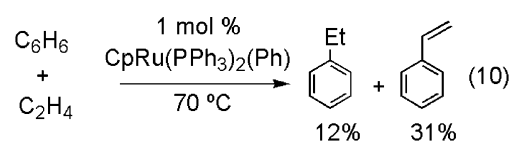

more facile production of styrene by the CpRu system compared with the TpRu system might be explained by 


\section{Scheme 8. Mechanism for Benzene $\mathrm{C}-\mathrm{H}$ Activation by $(\mathrm{Tab}) \mathrm{Ru}(\mathrm{NCH})(\mathrm{Me})$ with Calculated Free Energy Differences Given in kcal/mol}

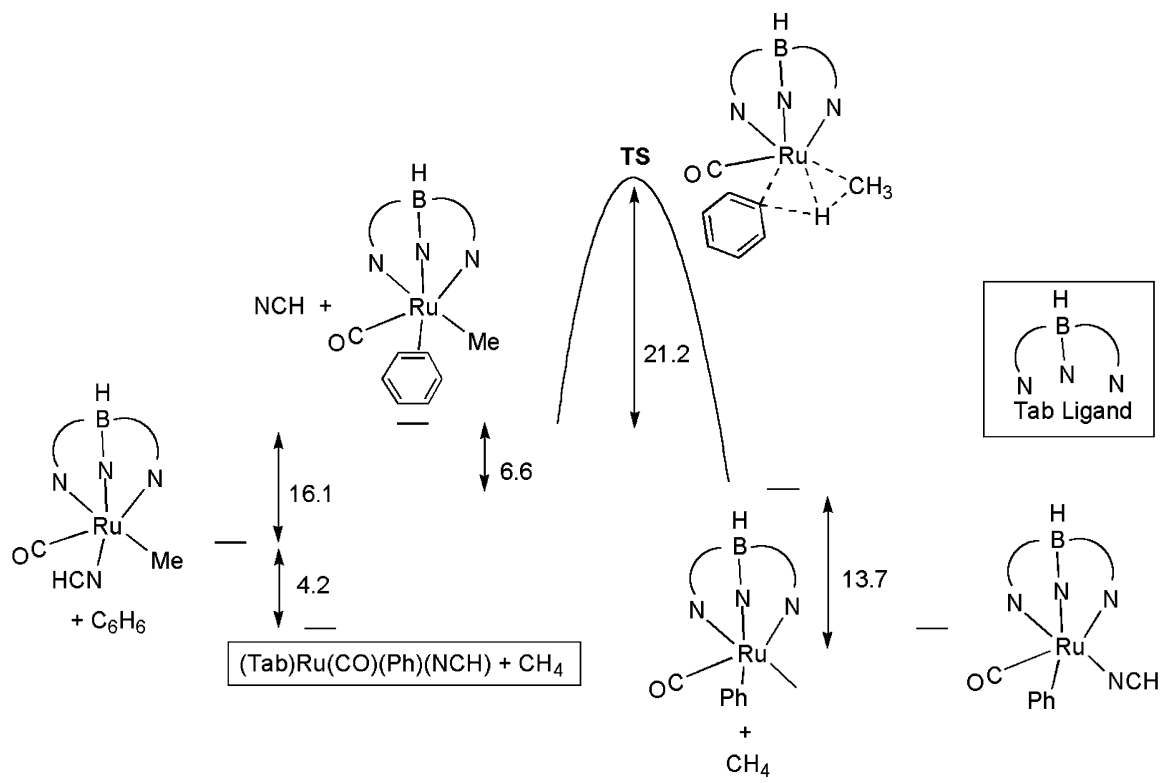

the ability of $\mathrm{Cp}$ to undergo a ring slip to provide a pathway for associativeligand exchange after $\beta$-hydride elimination. Thus, an $\eta^{5}$ to $\eta^{3}$ ring-slip would provide an open coordination site for binding of ethylene (or phosphine), and subsequent dissociation of styrene is likely to be facile. ${ }^{59}$ Although the production of ol efin accounts for a portion of the decomposition of the $\mathrm{CpRu}$ complex, ${ }^{31}$ P NMR spectroscopy indicates that the fate of the remaining $\mathrm{Ru}(\sim 70 \%)$ is dispersed between multiple uncharacterized complexes. Thus, the CpRu$\left(\mathrm{PPh}_{3}\right)_{2}(\mathrm{Ph})$ system apparently decomposes under catalytic conditions. A benzene solution of $\mathrm{CpRu}\left(\mathrm{PPh}_{3}\right)_{2}(\mathrm{Ph})$ under $25 \mathrm{psi}$ of propene at $70{ }^{\circ} \mathrm{C}$ produces less than stoichiometric quantities of cumene and n-propylbenzene. Using $5 \mathrm{~mol} \%$ of $\mathrm{CpRu}\left(\mathrm{PPh}_{3}\right)_{2}(\mathrm{Ph})$, an approximate 5:1 molar ratio of n-propyl benzene to cumene is produced (eq 11).

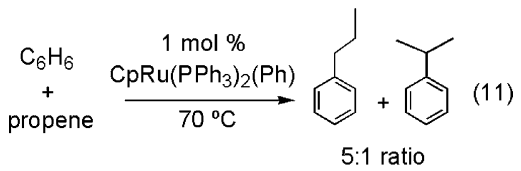

The reaction of (PCP)Ru(CO)(OTf) (PCP $=2,6-\left(\mathrm{CH}_{2} \mathrm{Pt}_{-}\right.$ $\left.\mathrm{Bu}_{2}\right)_{2} \mathrm{C}_{6} \mathrm{H}_{3}$ ) with $\mathrm{PhLi}$ allows the isolation of (PCP)Ru(CO)(Ph) (5) (eq 12). We anticipated complex 5 as a potential catalyst for the hydroarylation reactions since it has similar features to complex $\mathbf{1}$. For example, complex $\mathbf{5}$ possesses a tridentate (six-electron donating) monoanionic ligand ( $c f$. the ligand $\mathrm{Tp}$ ) as well as Ru$\mathrm{CO}$ and $\mathrm{Ru}-\mathrm{Ph}$ bonds. In addition, an open coordination site for olefin binding is available since complex $\mathbf{5}$ is coordi natively and electronically unsaturated. Complex $\mathbf{5}$ differs from $\mathbf{1}$ in that the tridentate ligand is coordinated in a meridonal fashion (versus facial for the Tp ligand) and the metal center is a more proficient $\pi$-base $\left(v_{\mathrm{CO}}=1900 \mathrm{~cm}^{-1}\right.$ for $\mathbf{5}$ compared with $1935 \mathrm{~cm}^{-1}$ for $\left.\mathbf{1}\right)$. A $0.5 \mathrm{~mol} \%$ solution of $\mathbf{5}$ in benzene under 25 psi of ethylene pressure at temperatures from 90 to $150{ }^{\circ} \mathrm{C}$ failed to produce detectable quantities of ethylbenzene; however, styrene was observed in $10-15 \%$ yield based on complex 5. Although the source of the lack of activity for olefin hydroarylation using $\mathbf{5}$ has not been definitively determined, the steric bulk due to the presence of four tBu groups as well as the potential for a trans orientation of coordinated olefin and the phenyl ligand could contribute to the poor activity. Consistent with the former, the coordination of Lewis bases (e.g., ammonia) to the (PCP)Ru(CO)(R) framework is particularly weak. 60

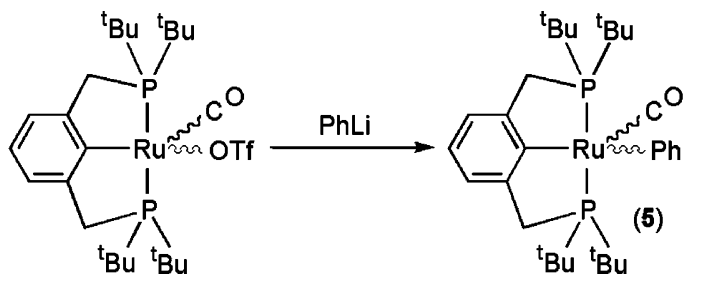

Computational Studies. In concert with the experimental studies, the catalytic hydroarylation of ethylene has been studied at the B3LYP/SBK (d) level of theory. As a model of the full tris(pyrazolyl)borate (Tp) ligand, the tris(azo)borate $(\mathrm{Tab})$ ligand, $\left[\mathrm{HB}(-\mathrm{N}=\mathrm{NH})_{3}\right]^{-}$, was used. In previous research, Tab was shown to reproduce the structure and energetics of the full Tp models for $\mathrm{C}-\mathrm{H}$ activation potential energy surfaces ${ }^{61}$ In addition, the parent nitrile HCN was substituted for acetonitrile. The $\mathrm{C}-\mathrm{H}$ activation event was broken down into three steps: benzene coordination, activation of benzene with elimination of methane, and coordination of HCN to the resulting phenyl complex (Scheme 8). Oxgaard and

(56) Lehmkuhl, H.; Grundke, J .; Mynott, R. Chem. Ber. 1983, 116, $159-175$.

(57) Lehmkuhl, H.; Bellenbaum, M.; Grundke, J .; Mauermann, H.; Krüger, C. Chem. Ber. 1988, 121, 1719-1728.

(58) Lehmkuhl, H.; Bellenbaum, M.; Grundke, J J J . Organomet. Chem. 1987, 330, C23-C26.

(59) O'Connor, J . M.; Casey, C. P. Chem. Rev. 1987, 87, 307-318. (60) Conner, D.; J ayaprakash, K. N.; Cundari, T. R.; Gunnoe, T. B. Organometallics 2004, 23, 2724-2733.

(61) Bergman, R. G.; Cundari, T. R.; Gillespie, A. M.; Gunnoe, T. B.; Harman, W. D.; Klinckman, T. R.; Temple, M. D.; White, D. P. Organometallics 2003, 22, 2331-2337. 


\section{Scheme 9. Calculated Energetics for Ethylene Coordination to (Tab)Ru(CO)(Ph), Ethylene Insertion into} the Ru-Ph Bond, and $\beta$-Hydride Elimination with Energy Differences Given in $\mathrm{kcal} / \mathrm{mol}$

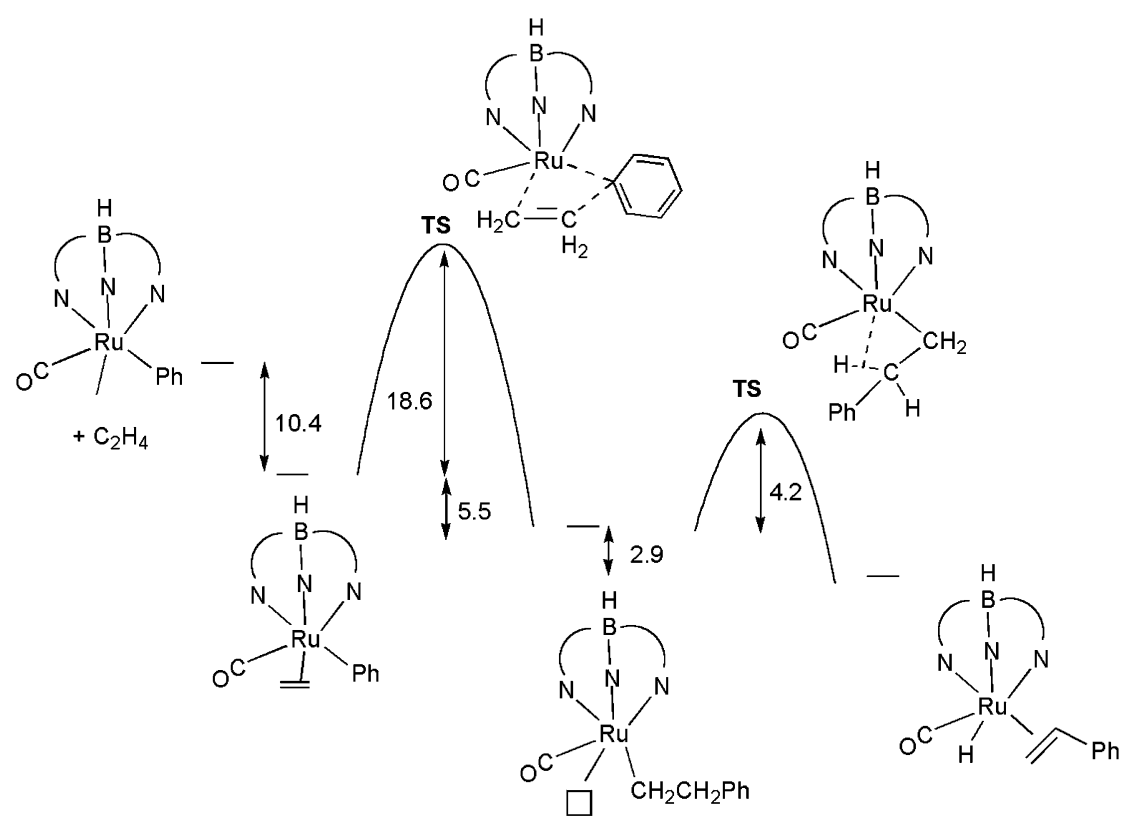

Goddard have recently communicated a computational study of the catalytic hydrophenylation of ethylene by $\mathrm{TpRu}(\mathrm{CO})(\mathrm{NCMe})(\mathrm{Ph})$; in cases where Oxgaard and Goddard studied similar reactions, computed enthal pies were comparable to those obtained with the smaller model employing Tab and HCN instead of Tp and $\mathrm{MeCN}$, respectively. ${ }_{4} 4$

Benzene $\mathbf{C}-\mathbf{H}$ Activation. The displacement of $\mathrm{HCN}$ by benzene is endergonic by $16.1 \mathrm{kcal} / \mathrm{mol}$. Given a calculated free energy of binding of $\mathrm{HCN}$ to $\{(\mathrm{Tab})$ $\mathrm{Ru}(\mathrm{Me})(\mathrm{CO})\}$ of $14.9 \mathrm{kcal} / \mathrm{mol}$, this corresponds to binding free energy to $\{(\mathrm{Tab}) \mathrm{Ru}(\mathrm{M} \mathrm{e})(\mathrm{CO})\}$ of $+1.2 \mathrm{kcal} / \mathrm{mol}$ for benzene and is consistent with the anticipated weak binding of a $\pi$-heteroaromatic system to a closed-shell, $\mathrm{d}^{6} \mathrm{ML}_{5}$ fragment. Subsequent $\mathrm{C}-\mathrm{H}$ activation of benzene to produce methane and $\{(\mathrm{Tab}) \mathrm{Ru}(\mathrm{CO})(\mathrm{Ph})\}$ is exergonic by $6.6 \mathrm{kcal} / \mathrm{mol}$ with a calculated free energy barrier of $21.2 \mathrm{kcal} / \mathrm{mol}$. The coordination of nitrile to $\{(\mathrm{Tab}) \mathrm{Ru}(\mathrm{CO})(\mathrm{Ph})\}$ is favorable by $-13.7 \mathrm{kcal} / \mathrm{mol}$, and the overall transformation of (Tab)Ru(CO)(Me)(NCH) and benzene to $(\mathrm{Tab}) \mathrm{Ru}(\mathrm{CO})(\mathrm{Ph})(\mathrm{NCH})$ and methane is exergonic by $4.2 \mathrm{kcal} / \mathrm{mol}$. If the overall entropy change for benzene $\mathrm{C}-\mathrm{H}$ activation by $(\mathrm{Tab}) \mathrm{Ru}(\mathrm{CO})(\mathrm{Me})(\mathrm{NCH})$ is considered negligible, using a bond dissociation energy of methane of 105 and $113 \mathrm{kcal} / \mathrm{mol}$ for benzene indicates that the Ru-phenyl bond is approximately 12 $\mathrm{kcal} / \mathrm{mol}$ stronger than the Ru-methyl bond. ${ }^{62}$

Ethylene I nsertion. I n the proposed catalytic cycle, dissociation of acetonitrile produces $\{\mathrm{TpRu}(\mathrm{CO})(\mathrm{Ph})\}$, and binding of ethylene yields the intermediate TpRu$(\mathrm{CO})(\mathrm{Ph})\left(\eta^{2}\right.$-ethylene). Subsequent ethylene insertion provides a route for $\mathrm{C}-\mathrm{C}$ bond formation, and these reaction steps were also studied using DFT with $\{(T a b)$ $\mathrm{Ru}(\mathrm{CO})(\mathrm{Ph})\}$ (Scheme 9). The free energy of ethylene binding to $(\mathrm{Tab}) \mathrm{Ru}(\mathrm{CO})(\mathrm{Ph})$ is $-10.4 \mathrm{kcal} / \mathrm{mol}$. The minimized structure of (Tab)Ru(CO)(Ph)( $\eta^{2}$-ethylene) is shown in Figure 4. Consistent with predictions based on $\mathrm{d} \pi$ back-bonding (see above), the ethylene $\mathrm{C}=\mathrm{C}$ bond

(62) Luo, Y.-R. Handbook of Bond Dissociation Energies in Organic Compounds; CRC Press: Boca Raton, 2003.

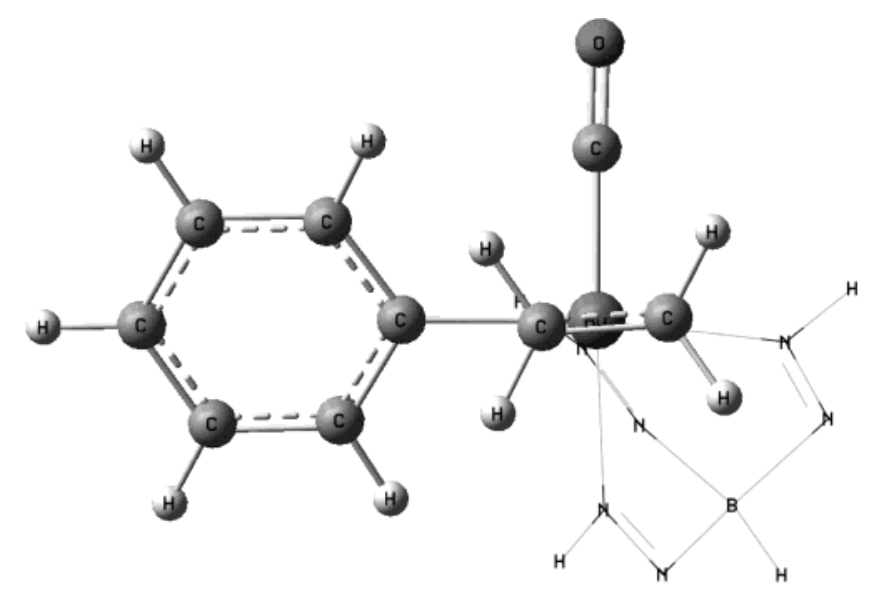

Figure 4. $B 3 L Y P / S B K(d)$ calculated structure of (Tab)$\mathrm{Ru}(\mathrm{CO})(\mathrm{Ph})\left(\eta^{2}\right.$-ethylene). Atoms of the Tab ligand are shown in wire frame for clarity.

is oriented approximately parallel to the $\mathrm{Ru}-\mathrm{Ph}$ bond. Combining the calculated olefin binding free energies with the HCN dissociation energies yields a free energy for $\mathrm{HCN} /$ ethylene exchange of $-3.3 \mathrm{kcal} / \mathrm{mol}$. The more favorable coordination of ethylene is consistent with the suggestion that $\mathrm{TpRu}(\mathrm{CO})\left(\mathrm{CH}_{2} \mathrm{CH}_{2} \mathrm{Ph}\right)\left(\eta^{2}\right.$-ethylene) is the catalyst resting state for the hydrophenylation of ethylene. The calculated ethylene insertion barrier is $18.6 \mathrm{kcal} / \mathrm{mol}$, and the insertion process is exergonic by $5.5 \mathrm{kcal} / \mathrm{mol}$.

Agostic Interactions and Resting State. The $\beta$-phenethyl complex, (Tab)Ru(CO) $\left(\mathrm{CH}_{2} \mathrm{CH}_{2} \mathrm{Ph}\right)$, which is the product of ethylene insertion into the $\mathrm{Ru}-\mathrm{Ph}$ bond of $\{(\mathrm{Tab}) \mathrm{Ru}(\mathrm{CO}) \mathrm{Ph}\}$, has a weak $\pi$-interaction involving the phenyl substituent, as evidenced by the calculated short distances between the ruthenium and ipso carbon $(\mathrm{Ru}-\mathrm{C}=2.75 \AA)$ as well as one of the ortho carbons $(\mathrm{Ru}-\mathrm{C}=2.61 \AA)$. The minimized structure of (Tab)Ru(CO) $\left(\mathrm{CH}_{2} \mathrm{CH}_{2} \mathrm{Ph}\right)$ is shown in Figure 5. This conformation leads to a Ru $-\mathrm{C}_{\alpha}-\mathrm{C}_{\beta}-\mathrm{C}_{\text {ipso }}$ di hedral angle of $-32^{\circ}$. An alternative conformation with this dihedral angle 


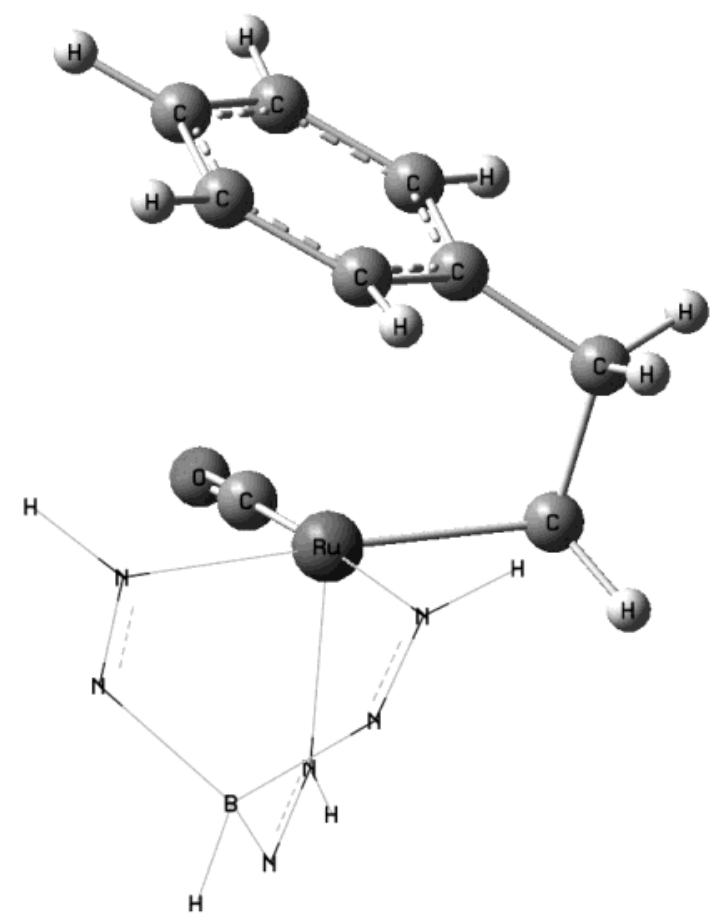

Figure 5. B3LYP/SBK(d) calculated structure of (Tab)$\mathrm{Ru}(\mathrm{CO})\left(\mathrm{CH}_{2} \mathrm{CH}_{2} \mathrm{Ph}\right)$. Atoms of the Tab ligand are shown in wire frame for clarity.

equal to $180^{\circ}$ was constructed, and geometry optimized at the same level of theory, resulting in a $\beta$-agostic (RuH $=1.93 \AA ; \mathrm{RuC}_{\beta}=2.44 \AA ; \mathrm{RuHC}_{\beta}=100^{\circ}$ ) interaction, which was calculated to be only $1.3 \mathrm{kcal} / \mathrm{mol}$ higher than the $\pi$-bonded conformation. The binding of ethylene to $\left\{(\mathrm{Tab}) \mathrm{Ru}(\mathrm{CO})\left(\mathrm{CH}_{2} \mathrm{CH}_{2} \mathrm{Ph}\right)\right\}$ to form the proposed resting state (Tab)Ru(CO) $\left(\mathrm{CH}_{2} \mathrm{CH}_{2} \mathrm{Ph}\right)\left(\eta^{2}\right.$-ethylene) is calculated to be cl ose to thermoneutral with $\Delta \mathrm{G}=+0.8 \mathrm{kcal} /$ mol.

$\boldsymbol{\beta}$-Hydride Elimination. The formation of (Tab)Ru$(\mathrm{CO})(\mathrm{H})\left(\eta^{2}\right.$-styrene) by $\beta$-H elimination from the most stable conformation of (Tab)Ru(CO) $\left(\mathrm{CH}_{2} \mathrm{CH}_{2} \mathrm{Ph}\right)$ has a calculated free energy barrier of $4.2 \mathrm{kcal} / \mathrm{mol}$ and is exergonic by $2.9 \mathrm{kcal} / \mathrm{mol}$ (Scheme 9 ). Given the likely assumption that a $\beta$-agostic minimum is the immediate precursor to the $\beta$-hydride elimination pathway, the free energy barrier is reduced and the driving force is enhanced by the calculated $1.3 \mathrm{kcal} / \mathrm{mol}$ energy difference between the $\pi$-coordinated and $\beta$-agostic forms of $\left\{(\mathrm{Tab}) \mathrm{Ru}(\mathrm{CO})\left(\mathrm{CH}_{2} \mathrm{CH}_{2} \mathrm{Ph}\right)\right\}$. The calculations are consistent with the experimental observation that $\beta$-hydride el imination is kinetically facile and reversible for $\mathrm{TpRu}(\mathrm{CO})(\mathrm{NCMe})\left(\mathrm{CH}_{2} \mathrm{CH}_{2} \mathrm{Ph}\right)$ (2).

Isolation of the Transition State for $\mathbf{C}-\mathbf{H}$ Activation. Detailed studies of stoichiometric $\mathrm{C}-\mathrm{H}$ activations by transition metal centers have revealed two common reaction pathways. Oxidative addition reactions dominate the chemistry of late transition metal complexes in low oxidation states, whereas $\sigma$-bond metathesis transformations occur when $d^{0}$ transition metal complexes initiate $\mathrm{C}-\mathrm{H}$ activation. ${ }^{3,63-66}$ Recent

(63) J ones, W. D.; Feher, F. J . Acc. Chem. Res. 1989, 22, 91-100.

(64) Thompson, M. E.; Baxter, S. M.; Bulls, A. R.; Burger, B. J .; Nolan, M. C.; Santarsiero, B. D.; Schaefer, W. P.; Bercaw, J . E. J . Am Chem. Soc. 1987, 109, 203-219. 56.

(65) Watson, P. L.; Parshall, G. W. Acc. Chem. Res. 1985, 18, $51-$

(66) Rothwell, I. P. Polyhedron 1985, 4, 177-200.

\section{Scheme 10. Two Possible Pathways for Ru(II)-Mediated C-H Activation}

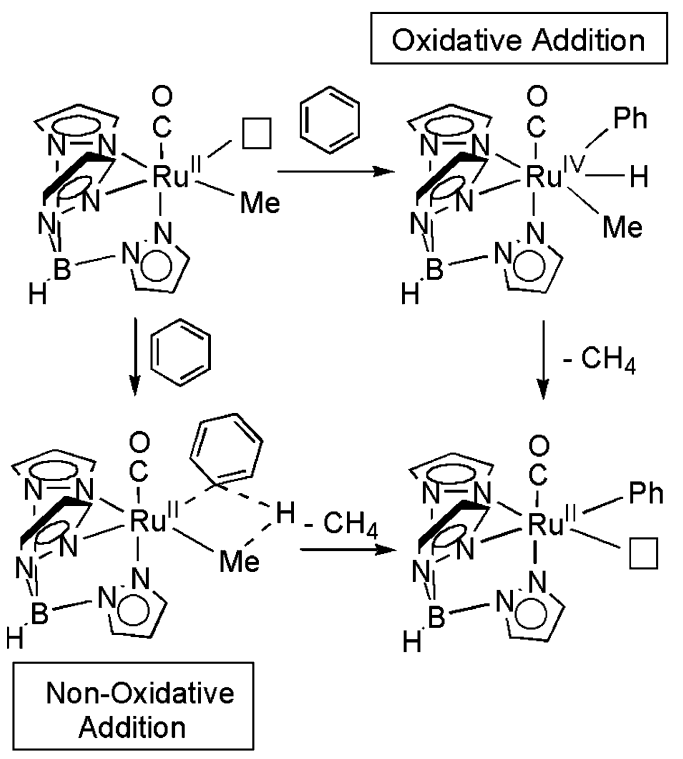

reports of $\mathrm{Ir}(\mathrm{III})$ systems that activate $\mathrm{C}-\mathrm{H}$ bonds have prompted speculation on the mechanism of the $\mathrm{C}-\mathrm{H}$ bond-breaking step of late transition metal systems for which oxidative addition would yield an unusually high formal oxidation state. ${ }^{41,67-73}$ To assist efforts to discern the $\mathrm{C}-\mathrm{H}$ activation pathway for catalysis using complex 1, DFT calculations have been employed for benzene $\mathrm{C}-\mathrm{H}$ activation by the $\left\{(\mathrm{Tab}) \mathrm{Ru}^{\prime \prime}(\mathrm{CO})(\mathrm{Me})\right\}$ fragment. Oxidative addition to form the Ru(IV) complex $\{(\mathrm{Tab})$ $\left.\mathrm{Ru}^{\prime V}(\mathrm{CO})(\mathrm{Me})(\mathrm{H})(\mathrm{Ph})\right\}$ (followed by reductive elimination of methane) and a non-oxidative addition reaction with simultaneous $\mathrm{C}-\mathrm{H}$ bond-breaking and bond-forming have been considered (Scheme 10).

Multiple pathways were investigated for the $\mathrm{C}-\mathrm{H}$ activation step including oxidative addition of a $\mathrm{C}-\mathrm{H}$ bond to $\{(\mathrm{Tab}) \mathrm{Ru}(\mathrm{CO}) \mathrm{Me}\}(\mathbf{A})$, oxidative addition of a methane $\mathrm{C}-\mathrm{H}$ bond to $\{(\mathrm{Tab}) \mathrm{Ru}(\mathrm{CO})(\mathrm{Ph})\}(\mathbf{B})$, and nonoxidative addition metathesis of a $\mathrm{C}-\mathrm{H}$ bond of benzene with the Ru- $\mathrm{CH}_{3}$ bond of $\{(\mathrm{Tab}) \mathrm{Ru}(\mathrm{CO}) \mathrm{Me}\}$ (C) (Scheme 11). Several different starting geometries were investigated for each of the proposed transition states. In all cases, the transition states collapsed to $\mathbf{C}$ (the nonoxidative addition transition state). The identity of the transition state was confirmed by calculation of the intrinsic reaction coordinate al ong the imaginary frequency, the primary motion of which corresponded to transfer of the transannular hydrogen from the methyl to the aryl carbon. The transition state geometry for $\mathrm{C}-\mathrm{H}$ activation of benzene is depicted in Figure 6 . The transannular hydrogen is only slightly closer to the ipso carbon $(1.49 \AA)$ than the methyl carbon $(1.52 \AA)$. The ruthenium carbon distances in the transition state $(\mathrm{Ru}-$

(67) Tellers, D. M.; Yung, C. M.; Arndtsen, B. A.; Adamson, D. R.; Bergman, R. G. J . Am. Chem. Soc. 2002, 124, 1400-1410.

(68) Arndtsen, B. A.; Bergman, R. G. Science 1995, 270, 1970-1972. 2717.

(70) Hinderling, C.; Feichtinger, D.; Plattner, D. A.; Chen, P. J . Am. Chem. Soc. 1997, 119, 10793-10804.

(71) Su, M.-D.; Chu, S.-Y.J . Am. Chem. Soc. 1997, 119, 5373-5383.

(72) Strout, D. L.; Zaric, S.; Niu, S.; Hall, M. B. J . Am. Chem. Soc. 1996, 118, 6068-6069.

(73) Oxgaard, J .; Muller, R. P.; Goddard, W. A., III; Periana, R. A. J . Am. Chem. Soc. 2004, 126, 352-363. 


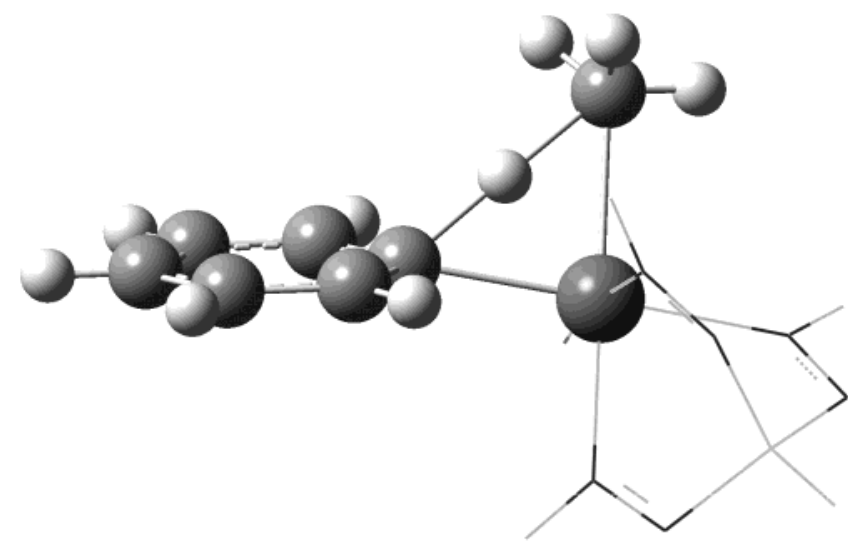

Figure 6. B $3 L Y P / S B K(d)$ calculated transition state for $\mathrm{C}-\mathrm{H}$ activation of benzene by (Tab)Ru(Me)(CO) (atoms of the Tab ligand are shown in wire frame for clarity). View of calculated transition state illustrates the "out-of-plane" position of the hydrogen atom undergoing transfer.

\section{Scheme 11. Pathways for C-H Activation Investigated by DFT Studies}
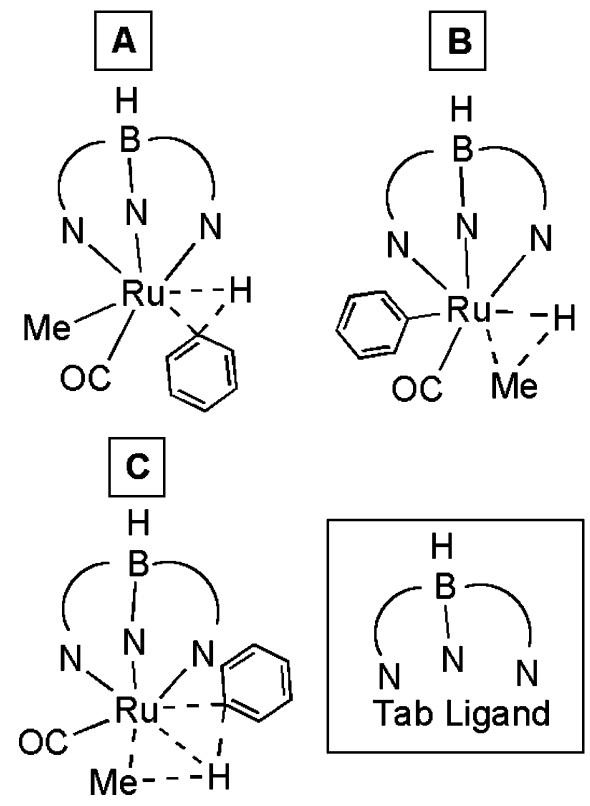

$\mathrm{C}_{\text {ipso }}=2.23 \AA ; \mathrm{Ru}-\mathrm{C}_{\mathrm{Me}}=2.31 \AA$ ) are only slightly longer (ca. 5-6\%) than ground state bond lengths.

Although the calculations indicate that the pathway for benzene $\mathrm{C}-\mathrm{H}$ activation does not involve an oxidative addition pathway (i.e., no Ru(IV) intermediate was found), the calculated distance between the Ru metal center and hydrogen (1.72 $\AA$ ) in the $\mathrm{C}-\mathrm{H}$ activation transition state is relatively short. Calculations by Oxgaard and Goddard reveal a $\mathrm{Ru}-\mathrm{H}$ distance of 1.61 $\AA$ in the transition state for benzene $\mathrm{C}-\mathrm{H}$ activation by $\mathrm{TpRu}(\mathrm{CO})\left(\mathrm{CH}_{2} \mathrm{CH}_{2} \mathrm{Ph}\right){ }^{44} \mathrm{Closely}$ related results have been reported from calculations to probe the mechanism of $\mathrm{C}-\mathrm{H}$ activation for $\mathrm{TpM}\left(\mathrm{PH}_{3}\right)(\mathrm{Me})(\mathrm{M}=\mathrm{Fe}$ or $\mathrm{Ru}$ ) complexes in which the authors suggested that the reaction pathway is intermediate between oxidative addition and $\sigma$-bond metathesis processes. ${ }^{74}$ Computational studies of methane activation by $\mathrm{Pt}\left(\mathrm{H}_{2} \mathrm{O}\right) \mathrm{Cl}_{2}$ indicate a similar four-center transition state with a

(74) Lam, W. H.; J ia, G.; Lin, Z.; Lau, C. P.; Eisenstein, O. Chem. Eur. J . 2003, 9, 2775-2782.
$\mathrm{Pt}-\mathrm{H}$ distance of $1.99 \AA .{ }^{75}$ Calculations on the transition state of benzene $\mathrm{C}-\mathrm{H}$ activation by (acac) ${ }_{2} \mathrm{I}\left(\mathrm{CH}_{2} \mathrm{CH}_{2-}\right.$ $\mathrm{Ph}$ ) reveals an $\mathrm{Ir}-\mathrm{H}$ distance of $1.58 \AA$, and Goddard et al. have differentiated this transition state (in which there is a metal-hydrogen interaction) from a $\sigma$-bond metathesis transition state using the label oxidative hydrogen migration. ${ }^{73}$

\section{Summary and Conclusions}

TpRu(CO)(NCMe)(Ph) (1) catalyzes the hydroarylation of olefins through a pathway that likely involves olefin binding and insertion into the $\mathrm{Ru}-\mathrm{Ph}$ bond foll owed by metal-mediated $\mathrm{C}-\mathrm{H}$ activation. Reactions that incorporate $\alpha$-olefins are mildly selective for production of linear over branched alkyl benzene products. Although the yields are poor, the selectivity for the hydrophenylation of propene using $\mathrm{CpRu}\left(\mathrm{PPh}_{3}\right)_{2}(\mathrm{Ph})$ (5:1 linear-to-branched ratio) indicates that ligand architecture can be used to control the regioselectivity of ol efin insertion. For reactions that incorporate ethylene, $\beta$-hydride eliminations to ultimately yield free styrene are not competitive with hydrophenylation, and this observation is attributed to reversible $\beta$-hydride elimination under catalytic conditions. The reversibility is likely a result of a relatively strong $\mathrm{Ru}$-styrene bond due to the metal $\pi$-basicity with suppression of associate exchange due to the coordinative saturation of TpRu$(\mathrm{CO})(\mathrm{H})\left(\eta^{2}\right.$-styrene). I contrast, following insertion of an $\alpha$-ol efin into the Ru-Ph bond, $\beta$-hydride elimination and ol efin dissociation are competitive with catalytic hydrophenylation of the ol efin. The similarities between catalytic ol efin hydrophenylation using $\mathrm{TpRu}(\mathrm{CO})(\mathrm{Ph})$ (NCMe) or Ir(III) phenyl complexes reported by Periana et al. are noteworthy, and computational/experimental studies indicate the likelihood of closely related reaction pathways including the $\mathrm{C}-\mathrm{H}$ activation step. ${ }^{40,41,73}$ However, evidence for $\beta$-hydride el imination and olefin dissociation has not been obtained for the Ir(III) systems, whereas such reactions have been observed with the $\mathrm{Ru}(\mathrm{II})$ systems reported herein. Similar to our experimental results with $\mathrm{Ru}(\mathrm{II})$, calculations by $\mathrm{Ox}$ gaard and Goddard suggest that $\beta$-hydride elimination for $\operatorname{Ir}(\mathrm{III})$ is facile and reversible. ${ }^{73}$

DFT studies suggest that the $\mathrm{C}-\mathrm{H}$ activation steps of the catalytic cycles do not proceed through a Ru(IV) oxidative addition intermediate, and the Tp ligand may deter processes that lead to seven-coordinate Ru(IV) systems. ${ }^{61}$ As previously discussed, ${ }^{64,76,77}$ for $\mathrm{C}-\mathrm{H}$ activations that proceed without an oxidative addition intermediate a distinction can be made between $\sigma$-bond metathesis and electrophilic aromatic substitution. The calculated transition state for benzene $\mathrm{C}-\mathrm{H}$ activation by $\left\{(\mathrm{Tab}) \mathrm{Ru}(\mathrm{CO})\left(\mathrm{CH}_{3}\right)\right\}$ reveals that the hydrogen atom undergoing transfer to the methyl ligand is out of the aromatic plane (Figure 6). The hydrogen atom is calculated to be $0.87 \AA$ removed from the "best" plane of the aromatic ring with a $\mathrm{H}-\mathrm{C}-\mathrm{Ru}$ angle of $50.3^{\circ}$, and the "out-of-phase" transannular hydrogen could be

(75) Siegbahn, P. E. M.; Crabtree, R. H. J . Am. Chem. Soc. 1996 $118,4442-4450$.

(76) Bulls, A. R.; Schaefer, W. P.; Serfas, M.; Bercaw, J . E. Organometallics 1987, 6, 1219-1226.

(77) Chesnut, R. W.; J acob, G. G.; Yu, J . S.; Fanwick, P. E.; Rothwell, I. P. Organometallics 1991, 10, 321-328. 
indicative of a $\mathrm{sp}^{2}$ to $\mathrm{sp}^{3}$ rehybridization of the ipso carbon that would be consistent with an electrophilic substitution pathway. Alternatively, the out-of-plane hydrogen could reflect progress along the reaction coordinate and incipient $\mathrm{Ru}-\mathrm{C}$ bond formation with the arene. The distinction between oxidative addition, $\sigma$-bond metathesis, oxidative hydrogen migration, and el ectrophilic aromatic substitution could have important implications for reactivity, and in order to probe this issue in more detail, we are currently studying the el ectronic influence of substituents on the arene.

\section{Experimental Section}

General Methods. All procedures were performed under inert atmosphere of dinitrogen in a Vacuum Atmospheres glovebox or using standard Schlenk techniques. The glovebox atmosphere was maintained by periodic nitrogen purges and monitored by an oxygen analyzer $\left\{\mathrm{O}_{2}(\mathrm{~g})<15 \mathrm{ppm}\right.$ for all reactions $\}$. Benzene, THF , and hexanes were purified by reflux over sodium followed by distillation. Pentane and methylene chloride were refluxed over $\mathrm{P}_{2} \mathrm{O}_{5}$ followed by distillation. Acetonitrile was dried over $\mathrm{CaH}_{2}$ and collected via distillation. Benzene- $d_{6}, C D_{2} \mathrm{Cl}_{2}, \mathrm{CD}_{3} \mathrm{CN}$, and $\mathrm{CDCl}_{3}$ were degassed by three freeze-pump-thaw cycles and stored over $4 \AA$ molecular sieves. ${ }^{1} \mathrm{H}$ and ${ }^{13} \mathrm{C}$ NMR spectra were recorded on a Varian Mercury $400 \mathrm{MHz}$ or a Varian Mercury $300 \mathrm{MHz}$ spectrometer. Resonances due to the Tp ligand are listed by chemical shift and multiplicity only (all coupling constants for the Tp ligand are $2 \mathrm{~Hz}$ ). Gas chromatography was performed on a HewlettPackard 5890 GC using either a J \&W SE-30 or an HP-5 capillary column ( $30 \mathrm{~m} \times 0.25 \mathrm{~mm} \mathrm{HP}-5$ column with $0.25 \mu \mathrm{m}$ film thickness) and an FID detector. Chromatograms were produced using either a Hewlett-Packard 3396A integrator or Perkin-Elmer TotalChrom 6.2 software. GC-MS was performed using a HP GCD system with a $30 \mathrm{~m} \times 0.25 \mathrm{~mm}$ HP-5 column with $0.25 \mu \mathrm{m}$ film thickness. Lecture bottles of ethylene (99.5\%) and propylene (99.0\%), 1-hexene, and decane were obtained from Sigma Aldrich Chemical Co. and used as received. Ethylene (99.5\%) was al so received in a gas cylinder from MWSC High-Purity Gases and used as received. All IR spectra were acquired using a Mattson Genesis II FTIR as thin films on $\mathrm{KBr}$ plates or as solutions. Pressure tube reactions were performed in either an ACG Lab-Crest glass pressure tube with Swagelock hardware or a Parr Instruments highpressure reactor. Cumene was obtained from Sigma Aldrich and dried over $\mathrm{CaH}_{2}$ prior to use. The preparation, isolation, and characterization of $\left[\mathrm{TpRu}(\mathrm{CO})_{2}(\mathrm{THF})\right]\left[\mathrm{PF}_{6}\right],{ }^{55} \mathrm{TpRu}(\mathrm{CO})$ (NCMe)(Ph) (1), ${ }^{43} \mathrm{TpRu}(\mathrm{CO})(\mathrm{NCMe})(\mathrm{Me}),{ }^{43} \mathrm{CpRu}\left(\mathrm{PPh}_{3}\right){ }_{2}(\mathrm{Me}),{ }^{57}$ $\mathrm{CpRu}\left(\mathrm{PPh}_{3}\right)_{2}(\mathrm{Ph}),{ }^{8}$ and $(\mathrm{PCP}) \mathrm{Ru}(\mathrm{CO})(\mathrm{OTf})$ have been previously reported. ${ }^{60}$

TpRu(CO)(NCMe)( $\left.\mathrm{CH}_{2} \mathrm{CH}_{2} \mathrm{Ph}\right)$ (2). TpRu(CO) $)_{2}\left(\mathrm{CH}_{2} \mathrm{CH}_{2-}\right.$ $\mathrm{Ph}$ ) (3) was dissolved in $20 \mathrm{~mL}$ of acetonitrile, and 1 equiv of $\mathrm{Me}_{3} \mathrm{NO}$ (based on amount of $\left[\mathrm{TpRu}(\mathrm{CO})_{2}(\mathrm{THF})\right]\left[\mathrm{PF}_{6}\right], 1.800$ $\mathrm{mmol}, 0.1352 \mathrm{~g}$ ) was added to the solution. The solution was refluxed for $1 \mathrm{~h}$. IR spectroscopy revealed the disappearance of absorptions at $v_{\mathrm{CO}}=2025$ and $1954 \mathrm{~cm}^{-1}$ and the appearance of a single CO absorption at $v_{\mathrm{CO}}=1917 \mathrm{~cm}^{-1}$. The volatiles were removed under reduced pressure to give a light yellow residue. The residue was dissolved in toluene and eluted on a column of neutral alumina. Two bands were observed, the first being dark yellow and the second being pale yellow. The second band was isolated. Toluene was removed by evacuation, yielding a pale yellow residue. Hexanes were added to the residue. After stirring overnight, a white solid was isolated by vacuum filtration $(0.153 \mathrm{~g}, 0.313 \mathrm{mmol}, 17 \%)$. ${ }^{1} \mathrm{H}$ NMR $\left(\mathrm{CDCl}_{3}, \delta\right): 7.73,7.67,7.60,7.54(6 \mathrm{H}$ total 1:3:1:1 ratio, each a d, Tp CH 3/5 position), $7.34\left(2 \mathrm{H}, \mathrm{d},{ }^{3} \mathrm{H} \mathrm{H}=8 \mathrm{~Hz}\right.$ phenyl ortho), $7.27\left(2 \mathrm{H}, \mathrm{t},{ }^{3} \mathrm{H}_{\mathrm{H}}=8 \mathrm{~Hz}\right.$, phenyl meta), 7.13 $\left(1 \mathrm{H}, \mathrm{t}, 3_{\mathrm{HH}}=8 \mathrm{~Hz}\right.$, phenyl para), $6.24(1 \mathrm{H}, \mathrm{t}, \mathrm{Tp} \mathrm{CH} 4$ position), $6.20(1 \mathrm{H}, \mathrm{t}, \mathrm{Tp} \mathrm{CH} 4$ position), $6.11(1 \mathrm{H}, \mathrm{Tp} \mathrm{CH} 4$ position), $3.03\left(2 \mathrm{H}, \mathrm{m}, \mathrm{Ru}-\mathrm{CH}_{2} \mathrm{CH}_{2} \mathrm{C}_{6} \mathrm{H}_{5}\right), 2.26(3 \mathrm{H}, \mathrm{s}, \mathrm{Ru}-$ $\left.\mathrm{NCCH}_{3}\right), 1.55\left(2 \mathrm{H}, \mathrm{m}, \mathrm{Ru}-\mathrm{CH}_{2} \mathrm{CH}_{2} \mathrm{C}_{6} \mathrm{H}_{5}\right) .{ }^{33} \mathrm{C}\left\{{ }^{1} \mathrm{H}\right\} \mathrm{NMR}\left(\mathrm{CDCl}_{3}\right.$, $\delta): 207.0$ (Ru-CO), 149.5 (ipso of Ru-phenyl), 143.5, 142.1, $140.0,135.4,134.7,134.6,128.2$ (ortho, meta, and para of phenyl, Tp 3 and 5 positions), 124.7 (Ru- $\mathrm{NCCH}_{3}$ ), 105.7, 105.4, 105.3 (Tp 4 positions), 42.6 ( $\mathrm{Ru}-\mathrm{CH}_{2} \mathrm{CH}_{2} \mathrm{Ph}$ ), $17.3\left(\mathrm{Ru}-\mathrm{CH}_{2} \mathrm{CH}_{2-}\right.$ $\mathrm{Ph}$ ), 4.3 (Ru-NCCH$)_{3}$. Anal. Calcd for $\mathrm{C}_{20} \mathrm{H}_{22} \mathrm{BN}_{7} \mathrm{ORu}$ : C 49.07, H 4.53, N 20.04. Found: C 49.00, H 4.59, N 20.13.

$\mathrm{TpRu}(\mathrm{CO})_{2}\left(\mathrm{CH}_{2} \mathrm{CH}_{2} \mathrm{Ph}\right)$ (3). A $50 \mathrm{~mL}$ round-bottom flask was charged with $0.375 \mathrm{~g}$ of $\left[\mathrm{TpRu}(\mathrm{CO})_{2} \mathrm{THF}^{\mathrm{T}}\left[\mathrm{PF}_{6}\right](0.643\right.$ $\mathrm{mmol}$ ) and $25 \mathrm{~mL}$ of benzene to yield a heterogeneous slurry. While stirring, 5 equiv of phenethylmagnesium chloride (1.0 $M$ in THF) were added dropwise to the benzene solution. Upon addition of the phenethylmagnesium chloride a homogeneous solution formed along with a color change from pale blue to honey gold. Analysis by IR spectroscopy reveal ed a change in CO absorption frequency from $v_{\mathrm{CO}}=2069$ and $2006 \mathrm{~cm}^{-1}$ to $v_{\mathrm{CO}}=2025$ and $1954 \mathrm{~cm}^{-1}$. Excess Grignard reagent was deactivated upon addition of distilled water. The organic layer was separated from the aqueous layer. The aqueous layer was then extracted with methylene chloride $(3 \times 50 \mathrm{~mL})$. The organic fractions were combined, and the volatiles were removed under reduced pressure to yield a golden brown oil. IR (THF): $v_{\text {CO }} 2025,1954 \mathrm{~cm}^{-1}$. ${ }^{1 H}$ NMR $\left(\mathrm{C}_{6} \mathrm{D}_{6}, \delta\right): 7.36,7.32$, $7.25,7.22,7.20,7.18,7.12$ (11 H, overlapping d's and t's, Tp $\mathrm{CH} 3$ and 5 position, Ru- $\left.\mathrm{CH}_{2} \mathrm{CH}_{2} \mathrm{C}_{6} \mathrm{H}_{5}\right), 5.71(1 \mathrm{H}, \mathrm{t}, \mathrm{Tp} \mathrm{CH} 4$ position), $5.68(2 \mathrm{H}, \mathrm{t}, \mathrm{Tp} \mathrm{CH} 4$ position), $3.38(2 \mathrm{H}, \mathrm{m}$, Ru- $\left.\mathrm{CH}_{2} \mathrm{CH}_{2} \mathrm{C}_{6} \mathrm{H}_{5}\right), 1.93\left(2 \mathrm{H}, \mathrm{m}, \mathrm{Ru}-\mathrm{CH}_{2} \mathrm{CH}_{2} \mathrm{C}_{6} \mathrm{H}_{5}\right) .{ }^{13} \mathrm{C}\left\{{ }^{1} \mathrm{H}\right\}$ NMR $\left(\mathrm{C}_{6} \mathrm{D}_{6}, \delta\right): 201.97$ (CO), 147.6 (ipso of phenyl), 143.6, $142.2,135.0,134.6,128.5,128.3,122.5$ (phenyl and Tp 3/5 position), 106.2, 105.9 (Tp 4 position), $44.5\left(\mathrm{Ru}-\mathrm{CH}_{2} \mathrm{CH}_{2} \mathrm{C}_{6} \mathrm{H}_{5}\right.$ ), $18.8\left(\mathrm{Ru}-\mathrm{CH}_{2} \mathrm{CH}_{2} \mathrm{C}_{6} \mathrm{H}_{5}\right)$.

TpRu(CO)(NCMe)(Cl) (4). TpRu(CO)(NCMe)(Me) $(0.150$ g, $0.377 \mathrm{mmol}$ ) was dissol ved in $30 \mathrm{~mL}$ of methylene chloride. $\mathrm{HCl}(0.377 \mathrm{~mL}, 1.0 \mathrm{M}$ in diethyl ether, $0.377 \mathrm{mmol})$ was added dropwise to the stirring solution at room temperature. Evolution of a gas was observed. An IR spectrum of the reaction solution revealed the disappearance of the $\mathrm{CO}$ absorption at $1919 \mathrm{~cm}^{-1}$ and the appearance of an absorption at $1968 \mathrm{~cm}^{-1}$. The vol atiles were removed under reduced pressure to give a pale yellow solid. The solid was washed with $10 \mathrm{~mL}$ of pentane and collected via vacuum filtration through a fine-porosity frit $(0.111 \mathrm{~g}, 0.265 \mathrm{mmol}, 71 \%)$. ${ }^{1} \mathrm{H}$ NMR $\left(\mathrm{CDCl}_{3}, \delta\right): 8.08,7.74$, 7.72, 7.68, 7.52 (each $1 \mathrm{H}$, each a d, Tp CH 3/5 position), 6.33, $6.20,6.16$ (each $1 \mathrm{H}$, each a t, Tp CH 4 position), 2.36 (3H, s, Ru-NCCH $\left.{ }_{3}\right) \cdot{ }^{13} \mathrm{C}\left\{{ }^{1} \mathrm{H}\right\} \mathrm{NMR}\left(\mathrm{CDCl}_{3}, \delta\right): 201.3$ (Ru-CO), 145.1, 144.5, 141.8, 136.1, 135.8, 134.9 (Tp 3 and 5 positions), 123.0 (Ru-NCCH 3 ), 106.7, 106.6, 106.2 (Tp 4 positions), 4.5 (Ru$\mathrm{NCCH}_{3}$ ). Anal. Calcd for $\mathrm{C}_{12} \mathrm{H}_{13} \mathrm{BCIN} \mathrm{ORu}_{7} \mathrm{O}\left(\mathrm{C}_{5} \mathrm{H}_{12}\right)_{0.15}$ (N ote: A ${ }^{1} \mathrm{H}$ NMR spectrum of the analysis sample indicates the presence of pentane in a 1/6.7 molar ratio with complex 4 ; a ${ }^{1} \mathrm{H}$ NMR spectrum of $\mathbf{4}$ is included in the Supporting I nformation): C 35.66, H 3.47, N 22.83. Found: C, 35.70, H, 3.29, N, 22.75.

(PCP)Ru(CO)(Ph) (5). In a $100 \mathrm{~mL}$ round-bottom flask, (PCP)Ru(CO)(OTf) $(0.1619 \mathrm{~g}, 0.2409 \mathrm{mmol})$ was dissolved in approximately $50 \mathrm{~mL}$ of THF. Phenyllithium $(0.265 \mathrm{mmol}, 1.8$ $M$ in ether) was added dropwise using a microsyringe. Upon addition of phenyllithium, a change in color from orange to dark red was observed. The volatiles were removed under reduced pressure, and the resulting solid was dissolved in approximatel y $30 \mathrm{~mL}$ of cyclopentane. After filtration through a fine-porosity frit the volatiles were removed under reduced pressure. The resulting dark red solid was dried in vacuo and collected $(0.0663 \mathrm{~g}, 0.1105 \mathrm{mmol}, 46 \%)$. IR (solution cell THF): $v_{\text {CO }} 1900 \mathrm{~cm}^{-1}$. ${ }^{1} \mathrm{H}$ NMR $\left(\mathrm{CD}_{2} \mathrm{Cl}_{2}, \delta\right): 7.46\left(1 \mathrm{H}, \mathrm{d},{ }^{3} \mathrm{Hн}\right.$ $=8 \mathrm{~Hz}$, phenyl ortho), $7.22\left(2 \mathrm{H}, \mathrm{d},{ }^{3} \mathrm{H} \mathrm{HH}=8 \mathrm{~Hz}, \mathrm{PCP} 3\right.$ and 5 position), $7.02\left(1 \mathrm{H}, \mathrm{t},{ }^{3} \mathrm{Hн}=8 \mathrm{~Hz}, \mathrm{PCP} 4\right), 6.58\left(1 \mathrm{H}, \mathrm{d},{ }^{3} \mathrm{Hн}\right.$ $=8 \mathrm{~Hz}$, phenyl ortho), $6.50\left(1 \mathrm{H}, \mathrm{t},{ }^{3} \mathrm{Hн}=8 \mathrm{~Hz}\right.$, phenyl meta or para), $6.37\left(1 \mathrm{H}, \mathrm{t},{ }^{3} \mathrm{Hн}=7 \mathrm{~Hz}\right.$, phenyl meta or para), 6.19 
$\left(1 \mathrm{H}, \mathrm{t},{ }^{3} \mathrm{\jmath н}=8 \mathrm{~Hz}\right.$, phenyl meta or para), $3.74\left(2 \mathrm{H}, \mathrm{dt},{ }^{2} \mathrm{~J} \mathrm{Hн}\right.$ $\left.=17 \mathrm{~Hz}, \mathrm{~J} \mathrm{PH}=8 \mathrm{~Hz}, \mathrm{P}-\mathrm{CH}_{2}\right), 3.55\left(2 \mathrm{H}, \mathrm{dt},{ }^{2} \mathrm{~J} \mathrm{HH}=17 \mathrm{~Hz}, \mathrm{JPH}\right.$ $\left.=9 \mathrm{~Hz}, \mathrm{CH}_{2}\right), 1.03-0.976\left(36 \mathrm{H}, \mathrm{m}, \mathrm{PCP}{ }^{\mathrm{B}} \mathrm{Bu}\right) .{ }^{13} \mathrm{C}\left\{{ }^{1} \mathrm{H}\right\} \mathrm{NMR}-$ $\left(C_{6} D_{6}, \delta\right): 208.9$ (t, $\left.{ }^{2} \mathrm{JPC}=9 \mathrm{~Hz}, \mathrm{CO}\right), 192.0\left(\mathrm{t},{ }^{2} \mathrm{~J} \mathrm{PC}=6 \mathrm{~Hz}\right.$, RuC), 157.4 (t, 2J PC = $10 \mathrm{~Hz}, \mathrm{Ph}$ ipso), 151.9 (vt, $\mathrm{N}=10 \mathrm{~Hz}$, PCP Ar or Ph), 146.0, 140.7, 125.9, 125.0 (each a s, each a PCP or Ph with one overlap), 121.0 (vt, $\mathrm{N}=16 \mathrm{~Hz}, \mathrm{PCP}$ Ar or $\mathrm{Ph}$ ), 119.4 (s, PCP or Ph), 38.2 (vt, N = 15 Hz, PC), 37.7 (vt, $\mathrm{N}=20 \mathrm{~Hz}, \mathrm{CH}_{2}$ ), 36.6 (vt, $\mathrm{N}=14 \mathrm{~Hz}, \mathrm{PC}$ ), 31.3, 29.4 (each a vt, $\left.\mathrm{N}=5 \mathrm{~Hz}, \mathrm{CH}_{3}\right) .{ }^{31} \mathrm{P}\left\{{ }^{1} \mathrm{H}\right\} \mathrm{NMR}\left(\mathrm{C}_{6} \mathrm{D}_{6}, \delta\right)$ : 77.4. Anal. Calcd for $\mathrm{C}_{31} \mathrm{H}_{48} \mathrm{OP}_{2} \mathrm{Ru}$ : C, 62.08, H, 8.07. Found: $\mathrm{C}, 63.01, \mathrm{H}, 8.10$ (Note: ${ }^{1 \mathrm{H}}$ and ${ }^{13} \mathrm{C} \mathrm{NMR}$ spectra revealed a small amount of cyclopentane in the analysis sample; ${ }^{1} \mathrm{H}$ and ${ }^{13} \mathrm{C}$ NMR spectra of $\mathbf{5}$ have been included in the Supporting I nformation).

Catalytic Reactions. A representative catalytic reaction is described. TpRu(CO)(NCMe)(Ph) (1) $(0.021 \mathrm{~g}, 0.046 \mathrm{mmol})$ was dissolved in $4.1 \mathrm{~mL}(0.0456 \mathrm{~mol})$ of benzene. To the homogeneous solution was added decane $(0.269 \mathrm{~mL}, 1.38$ $\mathrm{mmol}$ ) as an internal standard. The solution was placed in a thick-walled glass reaction vessel and charged with 25 psi of ethylene pressure. The tube was then placed in an oil bath heated to $90{ }^{\circ} \mathrm{C}$. Periodically the tube was removed from the oil bath and plunged into an ice bath. A $0.1 \mathrm{~mL}$ aliquot of the reaction solution was removed under a purge of dinitrogen, and the tube was quickly returned to the oil bath and ethylene pressure was restored. Samples $(\sim 1 \mu \mathrm{L})$ were removed from the aliquot and analyzed by GC-FID. With application of the appropriate correction factor (determined from regression plots of at least three sets of standard samples), the peak areas of the sample injection were used with the internal standard to calculate product yields.

Determination of Kinetic Isotope Effect. TpRu(CO)(NCMe)(Ph) (1) $(0.0511 \mathrm{~g}, 0.111 \mathrm{mmol})$ was dissolved in an equimolar solution of $\mathrm{C}_{6} \mathrm{H}_{6}(0.49 \mathrm{~mL}, 5.5 \mathrm{mmol})$ and $\mathrm{C}_{6} \mathrm{D}_{6}(0.53$ $\mathrm{mL}, 5.5 \mathrm{mmol}$ ). The solution was placed in a glass thick-walled pressure tube and placed under 25 psi ethylene. The pressurized tube was placed in an oil bath heated to $90^{\circ} \mathrm{C}$. After $2 \mathrm{~h}$, the pressure tube was removed from the oil bath and plunged into an ice bath. Aliquots were removed under a purge of dinitrogen and analyzed by GC/MS. Triplicate comparisons of the scaled isotopic abundance of fragment 111 to 112 (adjusted to account for fragmentation) were used to determine the kinetic isotope effect of 2.1(1). Repeating these experiments demonstrated reproducibility.

Kinetic Study of Catalytic Reactions. A sample determination of the rate of the formation of ethyl benzene catalyzed by $\mathrm{TpRu}(\mathrm{CO})(\mathrm{NCMe})(\mathrm{Ph})(\mathbf{1})$ at $70^{\circ} \mathrm{C}$ is given. A stock solution consisting of $0.069 \mathrm{~g}(0.149 \mathrm{mmol})$ of $\mathrm{TpRu}(\mathrm{CO})(\mathrm{NCMe})(\mathrm{Ph})$ (1) in $13.33 \mathrm{~mL}(0.149 \mathrm{~mol})$ of benzene was made. Decane (0.087 $\mathrm{mL}, 0.45 \mathrm{mmol}$ ) was added as an internal standard. Stock solution $(2.0 \mathrm{~mL})$ was added to a thick-walled glass pressure tube. The tube was placed under 15 psi ethylene pressure and heated to $70{ }^{\circ} \mathrm{C}$ in an oil bath. Periodically, the tube was removed from the oil bath and plunged into an ice bath. An aliquot of the solution was removed under a purge of dinitrogen, and the tube was placed under ethylene pressure and quickly returned to the oil bath. The aliquot was analyzed in triplicate by GC/FID.

$\mathbf{T p R u ( C O ) ( N C M e ) ( M e )}$ in $\mathbf{C}_{6} \mathbf{D}_{\mathbf{6}}$. Under nitrogen atmosphere, a screw-cap NMR tube was loaded with $0.020 \mathrm{~g}(0.050$ $\mathrm{mmol}$ ) of $\mathrm{TpRu}(\mathrm{CO})(\mathrm{NCMe})(\mathrm{Me})$ in $0.5 \mathrm{~mL}$ of $\mathrm{C}_{6} \mathrm{D}_{6}$. The tube was placed in an oil bath heated to $90^{\circ} \mathrm{C}$. After $1 \mathrm{~h}$ of heating, the tube was removed from the bath and allowed to cool to room temperature. $\mathrm{A}^{1} \mathrm{H}$ NMR spectrum was acquired revealing the production of $\mathrm{CH}_{3} \mathrm{D}$ (0.14 ppm, 1:1:1 triplet) and TpRu$(\mathrm{CO})(\mathrm{NCMe})\left(\mathrm{Ph}-\mathrm{d}_{5}\right)$.

Reaction of $\mathrm{TpRu}(\mathrm{CO})(\mathrm{NCMe})(\mathrm{Ph})$ with Ethylene in Acetonitrile. An acetonitrile solution ( $\sim 35 \mathrm{~mL}$ ) of TpRu(CO)$(\mathrm{NCMe})(\mathrm{Ph})(\mathbf{1})(0.118 \mathrm{~g}, 0.256 \mathrm{mmol})$ was placed under 250 psi of ethylene. The solution was heated to $90{ }^{\circ} \mathrm{C}$ for a period of $6 \mathrm{~h}$. The volatiles were removed under reduced pressure, leaving a yellow residue. A portion of the residue was dissolved in $\mathrm{C}_{6} \mathrm{D}_{6}$, and ${ }^{1}{ }^{1} \mathrm{H}$ NMR spectrum was acquired. The spectrum revealed two diamagnetic $\mathrm{TpRu}$ complexes including approximately $50 \%$ of $\mathrm{TpRu}(\mathrm{CO})(\mathrm{NCMe})\left(\mathrm{CH}_{2} \mathrm{CH}_{2} \mathrm{Ph}\right)$ (2). The second product is observed only at high ethylene pressures and remains uncharacterized.

Conversion of $\mathrm{CpRu}\left(\mathrm{PPh}_{3}\right)_{2}(\mathrm{Me})$ to $\mathrm{CpRu}\left(\mathrm{PPh}_{3}\right)_{2}(\mathbf{P h})$. A thick-walled screw-cap pressure tube was charged with 0.204 $\mathrm{g}$ of $\mathrm{CpRu}\left(\mathrm{PPh}_{3}\right)_{2}(\mathrm{Me})(0.280 \mathrm{mmol})$ and $15 \mathrm{~mL}$ of benzene. The tube was placed in an oil bath and heated to $70{ }^{\circ} \mathrm{C}$ for $48 \mathrm{~h}$. The reaction vessel was removed from the oil bath, cooled to room temperature, and purged into an inert atmosphere glovebox. The volatiles were removed under reduced pressure, leaving a dark amber residue. Washing of the residue with hexanes resulted in the formation of solid that was collected via vacuum filtration. Analysis of the solid by ${ }^{1} \mathrm{H} N M R$ spectroscopy revealed clean formation of $\mathrm{CpRu}\left(\mathrm{PPh}_{3}\right)_{2}(\mathrm{Ph})$.

X-ray Diffraction Study of $\mathrm{TpRu}(\mathrm{CO})(\mathrm{NCMe})\left(\mathrm{CH}_{2-}\right.$ $\mathbf{C H}_{2} \mathbf{P h}$ ) (2). Complex $\mathbf{2}$ was recrystallized by slow evaporation of a diethyl ether solution. A pale yellow crystal of TpRu(CO)( $\mathrm{NCMe})\left(\mathrm{CH}_{2} \mathrm{CH}_{2} \mathrm{Ph}\right.$ ) was covered in the perfluoropolyether PFO-XR 75 (Lancaster) and sealed under nitrogen in a glass capillary. The crystal was optically aligned on the four-circle of a Siemens P4 diffractometer equipped with a graphite monochromatic crystal, a Mo K $\alpha$ radiation source $(\lambda=0.71073$ $\AA)$, and a SMART CCD detector held at $5.084 \mathrm{~cm}$ from the crystal. Four sets of 20 frames each were collected using the $\omega$-scan method with a 10 s exposure time. Integration of these frames followed by reflection indexing and least-squares refinement produced a crystal orientation matrix for the monoclinic unit cell. Data collection consisted of the measure ment of a total of 1650 frames in five different runs covering a hemisphere of data. The program SMART (version 5.6) was used for diffractometer control, frame scans, indexing, orientation matrix calculations, least-squares refinement of cell parameters, and the data collection. ${ }^{78}$ All 1650 crystallographic raw data frames were read by the program SAINT (version 5/6.0) and integrated using 3D profiling algorithms. The resulting data were reduced to produce a total of 15685 reflections and their intensities and estimated standard deviations. An absorption correction was applied using the SADABS routine available in SAINT. The data were corrected for Lorentz and polarization effects as well as any crystal decay. Data preparation was carried out by using the program XPREP, which gave 5140 unique reflections $\left(R_{\text {int }}=4.58 \%\right)$ with indices $-15 \leq \mathrm{h} \leq 15,-15 \leq \mathrm{k} \leq 15,-20 \leq \mathrm{I} \leq 19$. The monoclinic space group was determined to be $\mathrm{P} 2 \mathrm{I} / \mathrm{C}$ (No. 14).

The structure was solved by a combination of direct methods and F ourier methods with the use of SHE LXTL6.1. ${ }^{78}$ I dealized positions for the hydrogen atoms were included as fixed contributions using a riding model with isotropic temperature factors set at 1.2 (aromatic protons) or 1.5 (methyl protons) times that of the adjacent carbon. The position of the $\mathrm{B}-\mathrm{H}$ proton was refined with a fixed isotropic temperature factor set at 1.2 times that of the boron atom. The positions of the methyl hydrogen atoms were optimized by a rigid rotating group refinement with idealized tetrahedral angles. Fullmatrix least-squares refinement, based on the minimization of $\sum \mathrm{W}_{\mathrm{i}}\left|\mathrm{F}_{\mathrm{o}}{ }^{2}-\mathrm{F}_{\mathrm{c}^{2}}\right|^{2}$, with $\mathrm{W}_{\mathrm{i}}^{-1}=\left[\sigma^{2}\left(\mathrm{~F}_{\mathrm{o}}{ }^{2}\right)+(0.0627 \mathrm{P})^{2}+0.0000 \mathrm{P}\right]$, where $\mathrm{P}=\left(\operatorname{Max}\left(\mathrm{F}_{0}^{2}, 0\right)+2 \mathrm{~F}_{c}^{2}\right) / 3$, converged to give final discrepancy indices of R1 $=0.0455$, wR2 $=0.1054$ for 3462 reflections with $\mathrm{I}>2 \sigma(\mathrm{I})$. The goodness of fit (GOF) value was 1.020. A correction for secondary extinction was not applied. The maximum and minimum residual electron density peaks in the final difference Fourier map were 1.063 and $-0.558 \mathrm{e} / \AA^{3}$, respectively. The linear absorption coefficient, atomic scattering factors, and anomal ous dispersion corrections were calcu-

(78) SMART, SAINT, and XPREP programs are part of the Bruker AXS crystallographic software package for single-crystal data collection, reduction, and preparation. 
lated from values from the International Tables for X-ray Crystallography. ${ }^{79}$

Computational Methods. Quantum calculations were carried out using the Gaussian 98 package. ${ }^{80}$ The B3LYP hybrid functional was employed for all calculations. ${ }^{81}$ Heavy atoms were described with the Stevens relativistic effective core potentials (ECPs) and valence basis sets (VBSs). ${ }^{82,83}$ The valence basis sets of main group elements were augmented with a d polarization function. This ECPNBS combination, termed SBK (d), has been validated for the calculation of a wide variety of transition metal properties in previous studies. ${ }^{84,85}$ As a model of the full (tris-pyrazolyl)borate (Tp) ligand, the tris(azo)borate (Tab) ligand, $\left[\mathrm{HB}(-\mathrm{N}=\mathrm{NH})_{3}\right]^{-}$, was used. In previous research, Tab was shown to faithfully reproduce the structure and energetics of the full Tp models for $\mathrm{C}-\mathrm{H}$ activation potential energy surfaces. ${ }^{61}$

All stationary points were fully optimized without symmetry constraint. Several conformations of the different ligands were investigated by torsion about the appropriate metal-ligand bonds; the lowest energy conformers found are used in the

(79) International Tables for X-ray Crystal lography; Kynoch Press: Birmingham, 1974; Vol. IV, p 55 (Present distributor, D. Reidel, Dordrecht).

(80) Frisch, M. J .; Trucks, G. W.; Schlegel, H. B.; Scuseria, G. E.; Robb, M. A.; Cheeseman, J . R.; Zakrzewski, V. G.; Montgomery] r., J. A.; Stratmann, R. E.; Burant, J. C.; Dapprich, S.; Millam, J. M. Daniels, A. D.; Kudin, K. N.; Strain, M. C.; Farkas, O.; Tomasi, J .; Barone, V.; Cossi, M.; Cammi, R.; Mennucci, B.; Pomelli, C.; Adamo, C.: Clifford, S.; Ochterski, J .; Petersson, G. A.; Ayala, P. Y.; Cui, Q. Morokuma, K.; Malick, D. K.; Rabuck, A. D.; Raghavachari, K.; Foresman, J. B.; Cioslowski, J .; Ortiz, J . V.; Baboul, A. G.; Stefanov, B. B.; Liu, G.; Liashenko, A.; Piskorz, P.; Komaromi, I.; Gomperts, R. Martin, R. L.; Fox, D. J .; Keith, T.; Al-Laham, M. A.; Peng, C. Y. Nanayakkara, A.; Challacombe, M.; Gill, P. M. W.; J ohnson, B.; Chen W.; Wong, M. W.; Andres, J. L.; Gonzalez, C.; Head-Gordon, M.; Replogle, E. S.; Pople, J. A. Gaussian 98, Revision A.9; Gaussian Inc: Pittsburgh, PA, 1998.

(81) Becke, A. D. J . Chem. Phys. 1993, 98, 5648-5652.

(82) Stevens, W. J .; Basch, H.; Krauss, M.J . Chem. Phys. 1984, 81 $6026-6033$.

(83) Stevens, W. J .; Krauss, M.; Basch, H.; J asien, P. G. Can. J Chem. 1992, 70, 612-613.

(84) Holland, P. L.; Cundari, T. R. Perez, L. L: Eckert, N. A.; Lachicotte, R. J . J . Am. Chem. Soc. 2002, 124, 14416-14424.

(85) Cundari, T. R.; Klinckman, T. R.; Wolczanski, P. T. J . Am Chem. Soc. 2002, 124, 1481-1487. analyses. The energy Hessian was calculated at all stationary points to characterize them as minima (no imaginary frequencies) or transition states (one and only one imaginary fre quency). The quoted energies indude zero-point, enthal py, and entropic corrections determined from unscaled vibrational frequencies calculated at the B3LYP/SBK (d) level of theory. All energetic determinations were done at $298.15 \mathrm{~K}$ and $1 \mathrm{~atm}$. Geometries of all isolated stationary points are given as Supporting I nformation.

Acknowledgment. T.R.C. acknowledges support by the Office of Energy Sciences, Office of Science, U nited States Department of Energy, for support of this research through Grant No. DE-F G02-97ER14811. T.B.G. acknowledges support by the Office of Basic Energy Sciences, Office of Science, United States Department of Energy, for support of this research through Grant No. DE-FG02-03ER 15490 and the Alfred P. Sloan Foundation (Research Fellowship). M.L. acknowledges GlaxoSmithKline for support through a graduate re search fellowship. Prof. Bruce Novak kindly provided the use of a high-pressure Parr reactor. Mass spectra were obtained at the Mass Spectrometry Facility for Biotechnology (NCSU). Partial funding for the facility was obtained from the North Carolina Biotechnology Center and the National Science Foundation. The authors also wish to thank the National Science Foundation (NSF) for support of C.M.B. under the Chemistry Research Experiences for Undergraduates (REU) Program (CHE-0097485).

Supporting Information Available: Cartesian coordinates for all optimized minima are given. Complete tables of crystal data, collection and refinement data, atomic coordinates, bond distances and angles, and anisotropic displacement coefficients for $\mathrm{TpRu}(\mathrm{CO})(\mathrm{NCMe})\left(\mathrm{CH}_{2} \mathrm{CH}_{2} \mathrm{Ph}\right)(2)$. ${ }^{1} \mathrm{H} \mathrm{NMR}$ spectra of complexes $\mathbf{4}$ and $\mathbf{5}$ and $a{ }^{13} \mathrm{C}$ NMR spectrum of complex 5. This material is available free of charge via the Internet at http://pubs.acs.org.

OM049404G 